\title{
25. COMPARISON OF GEOCHEMISTRY OF BASALTS FROM THE EAST PACIFIC RISE, OCP RIDGE, AND SIQUEIROS FRACTURE ZONE, DEEP SEA DRILLING PROJECT LEG 54
}

\author{
Susan E. Humphris, ${ }^{1}$ and Robert N. Thompson, Department of Geology, Imperial \\ College of Science and Technology, Prince Consort Road, London, England \\ and \\ Ian L. Gibson, ${ }^{2}$ and Giselle F. Marriner, Department of Geology, Bedford \\ College, London, England
}

\begin{abstract}
The evolution and chemical variation observed in basalts from the East Pacific Rise (EPR), OCP Ridge and Siqueiros fracture zone are discussed in terms of major oxide, trace and rare-earth element (REE) data. All the samples are tholeiitic, and in general are $\mathrm{Mg}$ poor and Ti-rich compared with basalts from the Mid-Atlantic Ridge. Their chondrite-normalized REE patterns are moderately depleted in light REE, and show Eu anomalies ranging from negligible (OCP Ridge) to small and negative (EPR and Siqueiros fracture zone).

Closed-system, fractional crystallization of plagioclase and ferromagnesian minerals is the dominant process in the evolution of these magmas to their erupted compositions. Enrichment factors of $\mathrm{Ce}$, $\mathrm{Nd}, \mathrm{Tb}, \mathrm{Yb}, \mathrm{Y}$, and $\mathrm{Hf}$ indicate that the extent of solidification required to produce the evolved form from the primitive end member is just under 50 per cent. However, evidence for local mantle heterogeneity is also provided by the ultra-incompatible elements - La, $\mathrm{Nb}, \mathrm{Ta}$, and $\mathrm{Th}-$ and by the range of $\mathrm{TiO}_{2}$ concentrations seen at fixed values of $\mathrm{FeO} * / \mathrm{MgO}$.

The origin of the OCP Ridge magmas is discussed, and an hypothesis is advanced for evolution beneath the EPR and migration laterally within the oceanic crust to the OCP Ridge site immediately before eruption.
\end{abstract}

\section{INTRODUCTION}

This paper presents a general petrographic description as well as major oxide and trace element analyses of basaltic samples recovered from the region of the East Pacific Rise (EPR) during Leg 54 of the Deep Sea Drilling Project.

Three major structural features were sampled in an area at about $9^{\circ} \mathrm{N}$ on the EPR. An east-west transect, consisting of four sites, was drilled on the western flank of the EPR - Sites 420, 421, 423, and Hole 429A. Site 427 was drilled in the deeper trough of the Siqueiros fracture zone near a north-facing scarp. Two sites Sites 422 and 428 - sampled the basement of the OCP Ridge, an east-west trending ridge which extends for about $100 \mathrm{~km}$. This Ridge appears to overprint the fabric, suggesting that it postdates the surrounding sea floor. It is surrounded by a small depression or "moat," which is particularly well developed on the

\footnotetext{
${ }^{1}$ Present address: Sea Education Association, Woods Hole, Massachusetts.

${ }_{2}$ Present address: Department of Land Resource Science, University of Guelph, Guelph, Ontario, Canada N1G 2W1.
}

northern side. Site 422 was situated in the northern "moat," and Site 428 on the southern side. The locations of all the sites are shown in Figure 1.

The purposes of this study are (1) to characterize chemically the oceanic crust in the region of the EPR at $9^{\circ} \mathrm{N},(2)$ to elucidate any chemical variations among the basalts that may be related to the structural features, and (3) to discuss the petrogenetic processes involved in the evolution of these magmas.

\section{METHODS}

Bulk-rock major oxide data were obtained by X-ray fluorescence (XRF) analysis on fused glass discs (Norrish and Hutton, 1969). $\mathrm{Sr}, \mathrm{Y}, \mathrm{Zr}, \mathrm{Rb}$, and $\mathrm{Nb}$ were also determined by XRF analysis on pressed powder discs. $\mathrm{FeO}$ was measured using the method of Whipple (1974), and $\mathrm{Fe}_{2} \mathrm{O}_{3}$ was obtained by the difference from the XRF determination of total iron. $\mathrm{H}_{2} \mathrm{O}^{+}$and $\mathrm{CO}_{2}$ contents were determined using a $\mathrm{CHN}$ analyzer. Results obtained for analyses of standard rocks are presented in Table 1 .

The concentrations of rare-earth elements were determined by instrumental neutron activation analysis (INAA). Details of the analytical techniques, and their accuracy and precision, are discussed in Wood et al. (1976). 


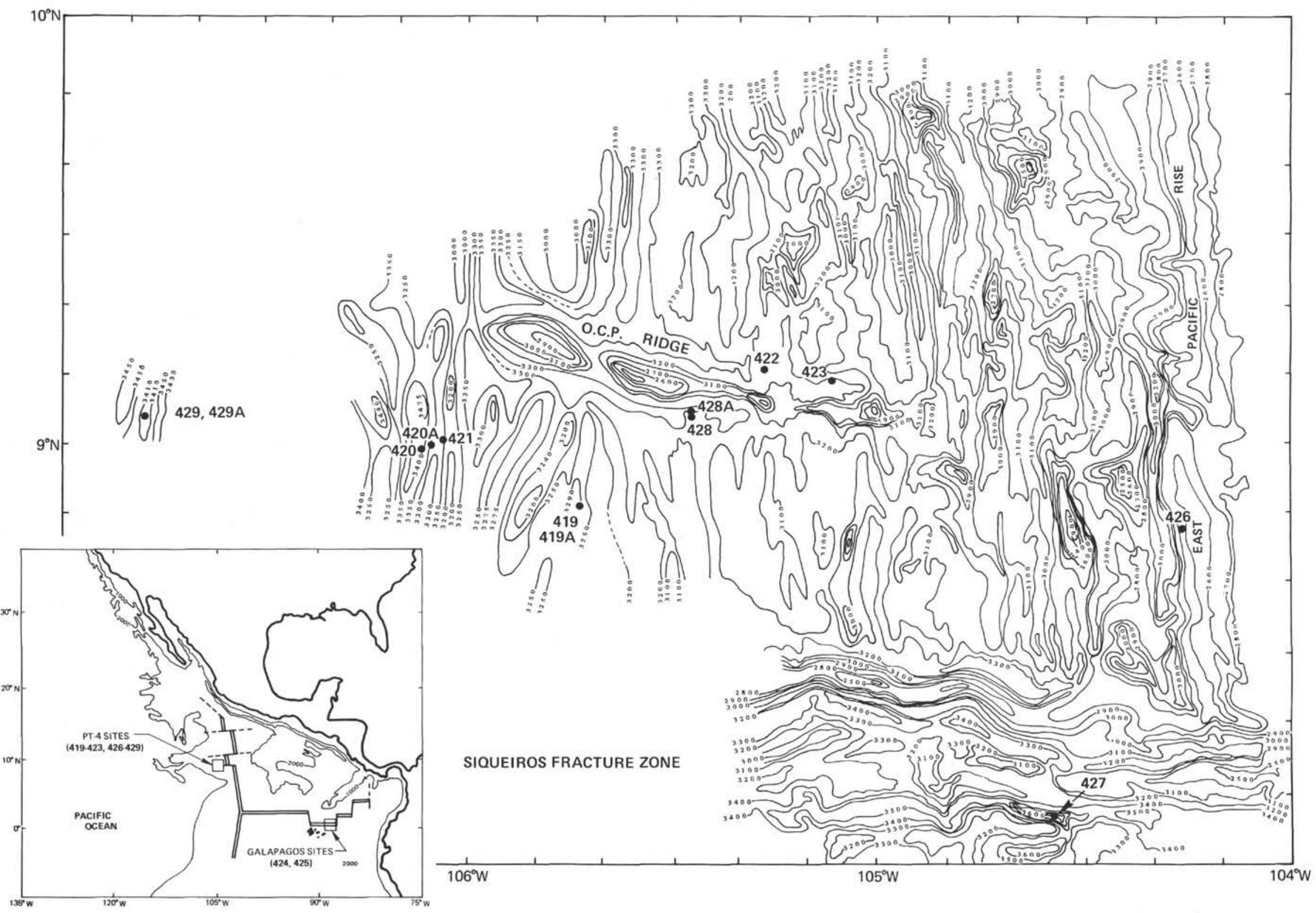

Figure 1. Locations of drilling sites on the East Pacific Rise during Leg 54. 
TABLE 1

Analyses of Reference Standards

\begin{tabular}{|c|c|c|c|}
\hline \multicolumn{4}{|c|}{ Major oxides in wt. \% } \\
\hline & W-1 & UB-N & NIM-N \\
\hline$\overline{\mathrm{SiO}_{2}}$ & $52.65(52.64)^{\mathrm{a}}$ & $39.44(39.40)$ & $52.53(52.43)$ \\
\hline $\mathrm{Al}_{2} \mathrm{O}_{3}$ & $15.15(15.00)$ & 3.17 (2.99) & $16.83(16.64)$ \\
\hline $\mathrm{Fe}_{2} \mathrm{O}_{3}$ & $1.44(1.40)$ & $5.31 \quad(5.52)$ & $1.00(1.05)$ \\
\hline $\mathrm{FeO}$ & $8.69(8.72)$ & $2.78 \quad(2.70)$ & $7.47 \quad(7.27)$ \\
\hline $\mathrm{MgO}$ & $6.66 \quad(6.62)$ & $34.94(35.00)$ & $7.76 \quad(7.43)$ \\
\hline $\mathrm{CaO}$ & $10.84(10.96)$ & $1.31 \quad(1.12)$ & $11.61(11.61)$ \\
\hline $\mathrm{Na}_{2} \mathrm{O}$ & $2.34 \quad(2.15)$ & $0.13 \quad(0.12)$ & $2.54(2.54)$ \\
\hline $\mathrm{K}_{2} \mathrm{O}$ & $0.68 \quad(0.64)$ & $0.05 \quad(0.02)$ & $0.26 \quad(0.26)$ \\
\hline $\mathrm{TiO}_{2}$ & $1.09(1.07)$ & $0.13 \quad(0.12)$ & $0.21 \quad(0.19)$ \\
\hline $\mathrm{P}_{2} \mathrm{O}_{5}$ & $0.14 \quad(0.14)$ & $0.03 \quad(0.03)$ & $0.05 \quad(0.04)$ \\
\hline $\mathrm{MnO}$ & $0.18 \quad(0.17)$ & $0.13 \quad(0.12)$ & $0.18 \quad(0.17)$ \\
\hline $\mathrm{H}_{2} \mathrm{O}^{+}$ & $0.54 \quad(0.53)$ & $10.86(11.00)$ & $0.34(0.40)$ \\
\hline $\mathrm{CO}_{2}$ & $0.13(0.06)$ & $0.51 \quad(0.41)$ & $0.11 \quad(0.10)$ \\
\hline
\end{tabular}

Selected trace elements in ppm

\begin{tabular}{|c|c|c|c|c|}
\hline & W-1 & NIM-N & BCR-1 & $A G V-1$ \\
\hline $\mathrm{Rb}$ & 19 (21) & (9) & $45 \quad(46.6)$ & 68 (67) \\
\hline $\mathrm{Sr}$ & $183(190)$ & $255(254)$ & $314(330)$ & $662(657)$ \\
\hline Y & 19 (25) & (7) & $33 \quad(37.1)$ & $19(21.3)$ \\
\hline $\mathrm{Zr}$ & 87 (105) & $27 \quad(25)$ & $185(190)$ & $236(225)$ \\
\hline $\mathrm{Nb}$ & (9.5) & (2) & $15 \quad(13.5)$ & $15 \quad(15)$ \\
\hline
\end{tabular}

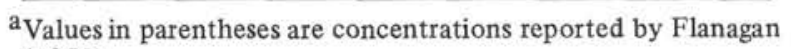
(1973).

\section{GENERAL PETROGRAPHY}

\section{EPR Flank Fabric Basalts}

The igneous rocks drilled in the flank fabric of the EPR consist of angular fragments of pillow lavas and flows, indicating that this area is characterized by welljointed, thin basaltic flows. Petrographically, our samples can be classified as plagioclase-clinopyroxene basalts, with aphyric, porphyritic, and glomerophyric varieties occurring throughout each hole. They are generally very fine grained with variolitic and intersertal textures, although in the more crystalline specimens, such as those from Hole 429A, intergranular and subophitic textures also occur. There is considerable variation in the degree of crystallinity, as well as crystal size and morphology within individual samples.

Plagioclase is the dominant phenocryst phase, and as such constitutes less than 1 per cent by volume. It forms equant and subequant euhedra $(0.1-1.5 \mathrm{~mm}$ in size) that show albite or Carlsbad twinning. Plagioclase occurs either as the only phenocryst phase (e.g., in Sample 54-421-3, 1-8 cm), when it is zoned with $\mathrm{An}_{82-83}$ cores and $\mathrm{An}_{71-72}$ rims, or with clinopyroxene (e.g., in Sample $54-423-8,1-4 \mathrm{~cm}$ ) when it is unzoned and has a composition of $\mathrm{An}_{71}$. Most of the zoned phenocrysts display a compositional gap of 7 to 9 per cent An content between the core and rim. Others are zoned continuously to the An content of the glomerophyric plagioclase. Plagioclase $\left(\mathrm{An}_{64-70}\right)$ occurs as skeletal crystals in glomerophyric clusters with clinopyroxene, or olivine, or both. Clinopyroxene phenocrysts $\left(\mathrm{Ca}_{41} \mathrm{Mg}_{49} \mathrm{Fe}_{10}\right)$ are observed in several samples (e.g., Samples 54-423-8, $1-4 \mathrm{~cm}$ and $54-420-16,1-1 \mathrm{~cm}$ ), with euhedral or subhedral morphologies, and ranging in size from 0.1 to $0.6 \mathrm{~mm}$. Glo- merophyric clinopyroxene is subhedral or skeletal, and is more iron-rich than the phenocrysts. Olivine, when present, occurs only in minor amounts as skeletal crystals of composition $\mathrm{FO}_{78-87}$. Titanomagnetite is the principal opaque phase, often constituting up to 7 per cent by volume of the rock. Spheres of pyrite are also observed, particularly in Hole 421 basalts.

\section{OCP Ridge Basalts}

The thick cooling units (up to $9 \mathrm{~m}$ ) that were recovered from the moat of the OCP Ridge (Holes 422, 428, and $428 \mathrm{~A}$ ) probably represent flows that have been restricted in extent by structural depressions. They are characterized by chilled glassy margins that grade rapidly into coarse-grained equigranular or porphyritic basalts in the centers of the units. Texturally, they range between variolitic, sub-intersertal, and strongly ophitic. The coarser grained samples tend to show the most ophitic textures, but still often contain glassy areas that sometimes show variolitic, sheaf-like structures and the main concentrations of opaque phases.

Mineralogically, the units are mainly plagioclase phyric and contain glomerocrysts of plagioclase with either clinopyroxene or olivine. The plagioclase phenocrysts are euhedral to subhedral, multiply-twinned and sometimes show oscillatory zoning. The composition of the cores is usually calcic bytownite $\left(\mathrm{An}_{82-86}\right)$. Plagioclase also occurs as skeletal, zoned, lath-like crystals with $\mathrm{An}_{75-77}$ cores in glomerophyric clusters with clinopyroxene or, more rarely, olivine. The clinopyroxene occurs as both subhedral and skeletal crystals, reaching up to 1 $\mathrm{mm}$ in length in Hole 428. The latter are generally augite in composition and show complex, irregular sector zoning. This is investigated further in Thompson and Humphris (this volume). Olivine $\left(\mathrm{Fo}_{83-87}\right)$ is present in glomerocrysts with plagioclase either as skeletal or equant crystals, generally in concentrations of less than 1 per cent by volume. Titanomagnetite occurs as moderate to large subhedral to euhedral crystals. Vesicles are generally scarce, tending to occur in the finer grained samples; they are often filled with secondary clay minerals.

One fragment of an aphyric glassy basalt was recovered from the bottom of Hole 422 (Sample 54-422-10, $1-3 \mathrm{~cm}$ ) and was texturally and mineralogically distinct from the overlying doleritic units; it resembled more closely the basalts drilled on the flank fabric of the EPR. The groundmass, which consists of dark brown spherulites with microlites of plagioclase and clinopyroxene, contains thin, lath-like plagioclase and euhedral clinopyroxene phenocrysts.

\section{Siqueiros Fracture Zone Basalts}

Samples from Hole 427 in the Siqueiros fracture zone constitute a single cooling unit 25.5 meters thick. Texturally, the flow ranges from intersertal, intergranular to ophitic in the center, where the basalt is massive and medium-grained. Plagioclase phenocrysts are euhedral to subhedral with compositions in the range $\mathrm{An}_{67-74}$. These coexist with subhedral clinopyroxene phenocrysts, having compositions similar to those found in the EPR flank fabric samples. The groundmass is com- 
posed of lath-like plagioclase showing undulatory extinction, anhedral subophitic clinopyroxene, large subhedral titanomagnetite, and varying amounts (from less than $5 \%$ in the center to $70 \%$ near the margin) of strongly devitrified glass. Occasional large tubular vesicles and irregular vugs occur, and these are filled with clay minerals and calcite.

A more detailed discussion of the mineralogy, together with microprobe analyses of all the major phases, is presented in Thompson and Humphris (this volume). This study indicated that the near-surface crystallization history of the Siqueiros fracture zone basalts was one of simple liquidus coprecipitation of plagioclase and clinopyroxene. However, both the EPR flank fabric and the OCP Ridge basalts have undergone more complex crystallization sequences during their near-surface evolution. The earliest liquidus phenocrysts assemblage preserved in them is dominated by calcic plagioclase. This was followed by resorption and subsequent rapid crystallization of a more sodic plagioclase together with olivine and/or clinopyroxene in glomerophyric clusters.

\section{BULK-ROCK COMPOSITIONS}

Major oxide and trace element analyses of the basalts from the EPR, the OCP Ridge, and the Siqueiros fracture zone are listed in Tables 2, 3, and 4, respectively. In addition, microprobe analyses of two glasses - from Samples 429A-2-1 (Piece 4A) and 420-16-1 (Piece 1)are presented in Table 5 .

Although all the analyses in Tables 2, 3, and 4 are of samples that are petrographically fresh, it is apparent that many of them have $\mathrm{H}_{2} \mathrm{O}^{+}$contents much larger than the maximum value of $0.24 \mathrm{wt} . \%$ recorded by Delaney et al. (1978) for quenched glasses of ocean-floor basalts. We attribute this hydration to incipient sub-oceanic weathering - a process discussed in more detail by Humphris, Melson, and Thompson (this volume), who show that $\mathrm{K}_{2} \mathrm{O}$ and $\mathrm{FeO}^{* 3}$ are also enriched in the weathered samples. Comparison of the ratios $\mathrm{TiO}_{2} /$ $\mathrm{Al}_{2} \mathrm{O}_{3}$ and $\mathrm{K}_{2} \mathrm{O} / \mathrm{Al}_{2} \mathrm{O}_{3}$ in sets of samples from individual aphyric eruptive units (Tables 2, 3, and 4) show several instances where $\mathrm{TiO}_{2} / \mathrm{Al}_{2} \mathrm{O}_{3}$ is constant, while some of the values of $\mathrm{K}_{2} \mathrm{O} / \mathrm{Al}_{2} \mathrm{O}_{3}$ are anomalously high. The low $\mathrm{K}_{2} \mathrm{O}$ abundances recorded in the microprobe analyses of the two glasses (EDS microprobe detection limit for $\mathrm{K}_{2} \mathrm{O}$ is about $0.08 \%$ ), relative to all the bulk-rock analyses, is also consistent with a view that $\mathrm{K}_{2} \mathrm{O}$ is enriched in many (possibly all?) the Leg 54 samples, as a result of weathering. We concur with the opinion of Bougault et al. (1978) that the abundances of K (and Rb) in oceanfloor lavas, other than glasses, are related more to postmagmatic than to magmatic processes. In contrast, comparison of $\mathrm{FeO} * / \mathrm{Al}_{2} \mathrm{O}_{3}$ with $\mathrm{TiO}_{2} / \mathrm{Al}_{2} \mathrm{O}_{3}$ in individual aphyric eruptive units (Tables 2, 3 and 4 ) gives no grounds for postulating anomalous $\mathrm{FeO}^{*}$ enrichment in any of these "fresh" samples.

The C.I.P.W. norms of samples listed in Tables 2, 3, and 4 have been calculated with $\mathrm{Fe}_{2} \mathrm{O}_{3}$ fixed at 1.5 per cent, to correct for variable oxidation associated with the incipient weathering previously discussed. This value of $\mathrm{Fe}_{2} \mathrm{O}_{3}$ is at the upper end of the range for this oxide recorded in published analyses of ocean-floor basal-

${ }^{3}$ Expressed as total iron.

TABLE 2

Analyses of Basalts from EPR Sites

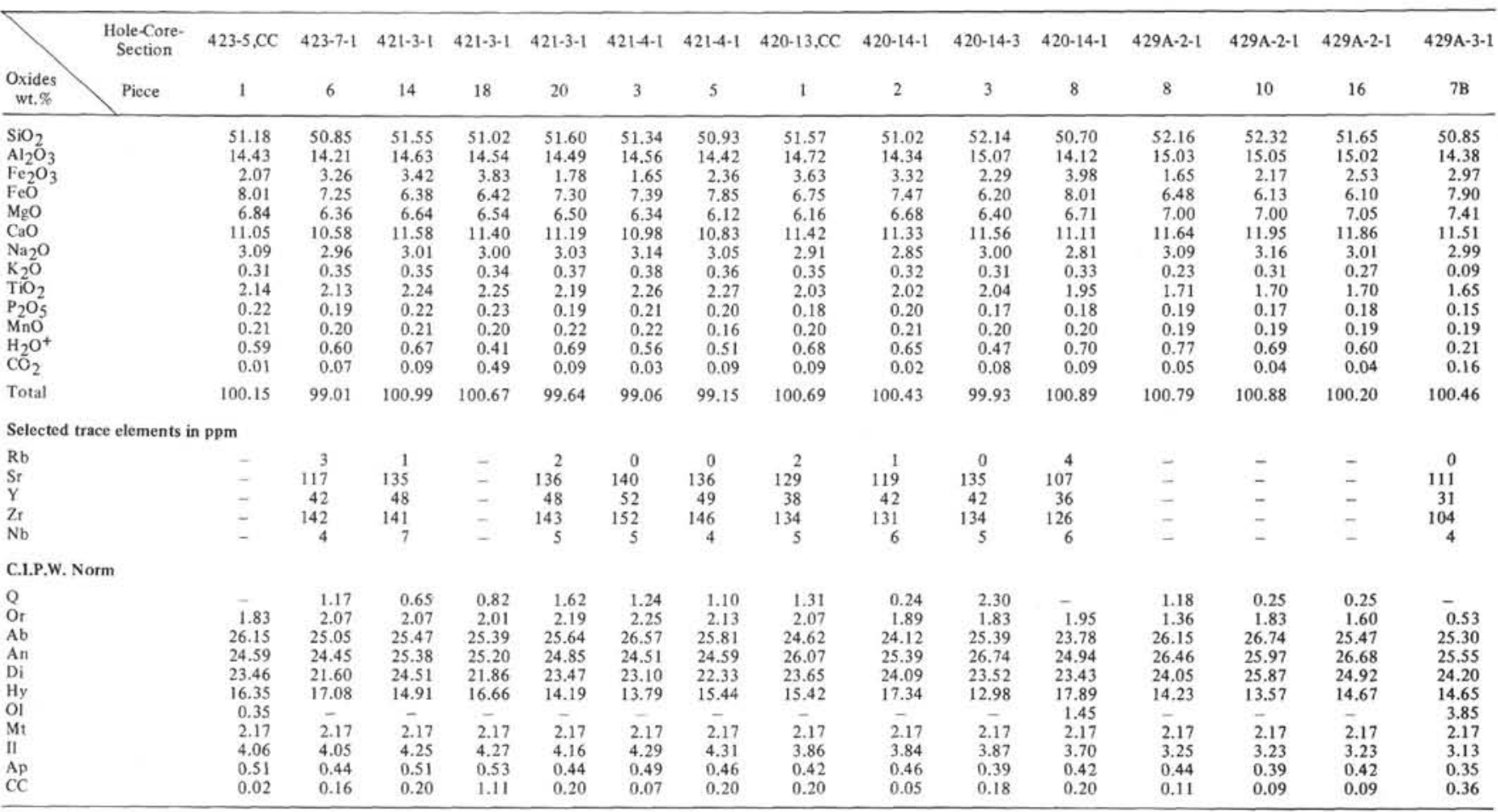


tic glasses. It may well be close to, or less than, the magmatic value of $\mathrm{Fe}_{2} \mathrm{O}_{3}$ in the $\mathrm{Fe}$-rich liquids which crystallized to the Hole 427 dolerites. The norms of all the samples recovered on Leg 54 from the EPR, OCP Ridge, and Siqueiros fracture zone are representative of typical tholeiitic ocean-floor basalts (Figure 2). They are therefore rather different from some of the dredged material from this region reported by Batiza et al. (1977), who found alkali basalts in the Siqueiros fracture zone. There also appears to be a normative separation of the Leg 54 basalts on Figure 2 according to their different tectonic environments. The EPR basalts in general either are $q z$-normative or are depleted in the ol component. Of the basalts that lie in the $d i$-hy-ol field, the Siqueiros fracture zone basalts are more $h y$-normative.

Table 6 compares the average compositions of basalts from each structural feature with averages of previously published data. The basalts recovered from all three tectonic features are (on average) Mg-poor and Ti-rich compared with basalts from the Mid-Atlantic Ridge (MAR), although they fall within the overall compositional range reported for the latter (Wood et al., 1979). The OCP Ridge basalts and the EPR basalts of the top eruptive unit in Hole 429A [Sample 2-1 (Piece 4A)] are very similar in composition to those previously analyzed from the EPR Rise and Nazca plate. However, the $\mathrm{TiO}_{2}$ contents of the other Leg 54 EPR samples and the Siqueiros fracture zone samples are at the high end of the range for this oxide recorded for worldwide mid-ocean ridge basalts.

Figure $3 \mathrm{a}-\mathrm{h}$ shows the variations in major oxide concentrations using the $\mathrm{FeO}^{*} / \mathrm{MgO}$ ratio as an indicator of fractionation. The scatter of points on the $\mathrm{K}_{2} \mathrm{O}$ $\mathrm{FeO} * / \mathrm{MgO}$ diagram is attributed to post-crystallization processes, as described previously. Figure 3 shows that, if the Leg 54 samples are treated as a single suite, they follow broad compositional trends of falling $\mathrm{Al}_{2} \mathrm{O}_{3}$, $\mathrm{CaO}$, and $\mathrm{MgO}$, approximately constant $\mathrm{Na}_{2} \mathrm{O}$, and rising $\mathrm{TiO}_{2}$ and $\mathrm{P}_{2} \mathrm{O}_{5}$, with increasing $\mathrm{FeO} * / \mathrm{MgO}$. As all of these samples are practically aphyric (Thompson and Humphris, this volume), it is clear that the variations in Figure 3 cannot be attributed in any part to phenocryst distribution, nor can they be explained completely by a simple hypothesis of fractional crystallization from a parental magma of unvarying composition. The $\mathrm{TiO}_{2}-$ $\mathrm{FeO} * / \mathrm{MgO}$ plot (Figure 3e) is particularly useful for this purpose, because $\mathrm{TiO}_{2}$ is immobile during weathering and may be determined with high precision during both XRF and microprobe analysis. Close inspection of Figure $3 \mathrm{e}$ shows that, within the overall broad positive correlation between $\mathrm{TiO}_{2}$ and $\mathrm{FeO}^{*} / \mathrm{MgO}$, each individual eruptive unit shows a separate trend of varying $\mathrm{FeO} * / \mathrm{MgO}$ at approximately constant $\mathrm{TiO}_{2}$. There are signs of similar sub-trends in the other diagrams of Figure 3.

The following points emerge when the major-oxide compositions of the Leg 54 basalts are considered in relation to the three distinct structural sites which were sampled. The compositions of the EPR flank fabric basalts show considerable scatter, both within and be- tween holes, with $\mathrm{MgO}=6.1-8.1$ per cent, $\mathrm{FeO}^{*}=$ $9.2-11.6$ per cent, and $\mathrm{TiO}_{2}=1.2-2.3$ per cent. The samples we have analyzed from Hole 429A overlap completely in major-oxide composition with the $\mathrm{OCP}$ Ridge basalts, except for the high $\mathrm{Al}_{2} \mathrm{O}_{3}$ contents of four samples in the lower part of Hole 422 [Samples 9-2 (Piece 4C), 9-2 (Piece 5A), 9-3 (Piece 8A), and 9-4 (Piece 5)].

The OCP Ridge lavas have ranges of $\mathrm{MgO}=6.9-8.4$ per cent, $\mathrm{FeO}^{*}=8.1-9.7$ per cent and $\mathrm{TiO}_{2}=1.4-1.6$ per cent. It is clear that neither these nor the Hole 429A basalts are sufficiently magnesian to be likely primary melts from the upper mantle, even at low pressures. Nevertheless, both contain early-precipitated olivine $\mathrm{Fo}_{87}$ (Thompson and Humphris, this volume) and are therefore not far evolved from primitive melts. Compared with other OCP Ridge lavas, the lower eruptive unit in Hole 422 shows higher $\mathrm{Al}_{2} \mathrm{O}_{3}$ (and $\mathrm{Sr}$ ) and lower $\mathrm{CaO}$.

The Siqueiros fracture zone samples from Hole 427 have ranges of $\mathrm{MgO}=6.6-6.8$ per cent, $\mathrm{FeO}^{*}=11.4$ 12.7 per cent, and $\mathrm{TiO}_{2}=2.1-2.6$ per cent. Thus, they resemble in composition the ferrobasalts from EPR spreading centers described by Clague and Bunch (1976).

\section{Minor Elements}

The abundances of $\mathrm{Rb}, \mathrm{Sr}, \mathrm{Y}, \mathrm{Zr}$, and $\mathrm{Nb}$ in most of the Leg 54 samples studied are given in Tables 2, 3, and 4. Rare-earth elements (REE), Th, Ta, and Hf in selected samples are listed in Table 7. The chondrite-normalized REE patterns of all these lavas (Figure 4) are very similar. They are concave downward, with moderate depletion of light (LREE) relative to heavy rareearths (HREE). It is clear from the overall shapes of these patterns, and from the few data sets where Sm, $\mathrm{Eu}, \mathrm{Gd}$, and $\mathrm{Tb}$ are all determined, that the Leg $54 \mathrm{sam}-$ ples have $\mathrm{Eu}$ anomalies ranging from negligible (OCP Ridge) to small and negative (EPR and the Siqueiros fracture zone). On a plot of the chondrite-normalized ratio $(\mathrm{Ce} / \mathrm{Yb})_{\mathrm{N}}$ against $\mathrm{Ce}_{\mathrm{N}}$ (Figure 5), the lavas from the three structural settings drilled during Leg 54 occupy different fields. Nevertheless, it should be emphasized that the scales of Figure 5 are inflated. Compared with the ranges of $(\mathrm{Ce} / \mathrm{Yb})_{\mathrm{N}}$ in lavas from individual holes drilled elsewhere during the DSDP - such as Holes 407, 409,411 , and 413 of Leg 49 (Wood et al., 1979) - it is the constancy of slope of the REE patterns (Figure 4) for all the Leg 54 samples which is striking.

Figures 6 through 9 are binary plots of various incompatible elements in the Leg 54 basalts. All these elements would be retained almost entirely in the residual liquid during fractional crystallization of olivine and/or plagioclase, but some of them would partition to a small extent into the separating solids if these included a large proportion of pyroxene or spinel. In contrast, the bulk partition coefficients $(D)$ between these elements and the mineral assemblages thought to characterize the upper mantle within the melting zone beneath spreading axes vary by about two orders of magnitude - between 
TABLE 3

Analyses of Basalts from the OCP Ridge

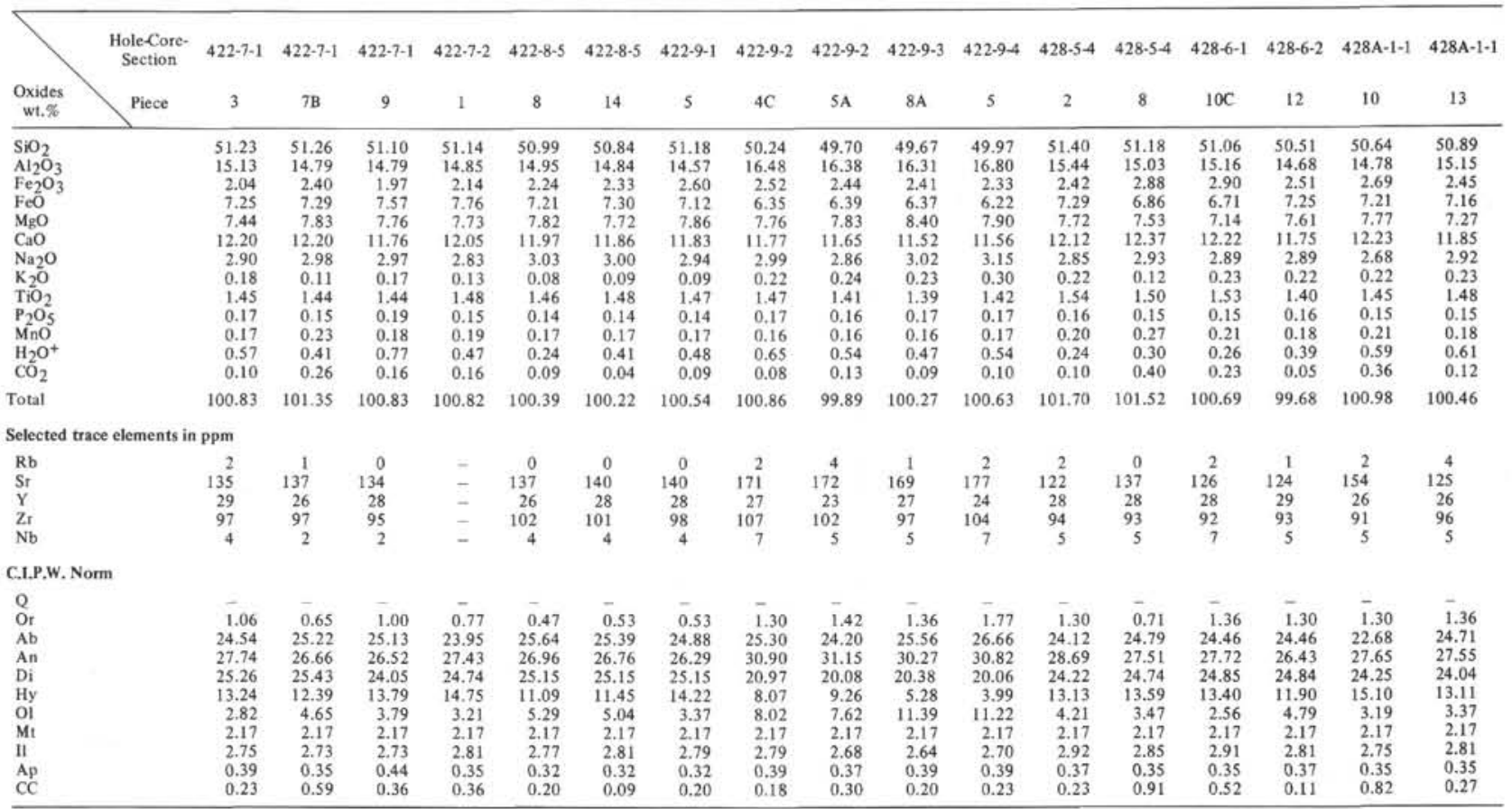

$\mathrm{Y}$ and $\mathrm{Yb}(D \sim 1.0)$ and $\mathrm{Th}, \mathrm{Ta}, \mathrm{Nb}$, and $\mathrm{La}(D \sim 0.01)$. This allows considerable inter-incompatible-element fractionation during low degrees of mantle partial fusion (Bougault et al., 1979). Therefore, binary plots of variably incompatible elements can be used to determine whether partial fusion (to different degrees) at genesis (with or without variable source composition) or subsequent fractional crystallization is the dominant process influencing the chemical variation shown by a suite of basalts.

All the data in Figures 6 through 8 show good fits to straight lines passing through zero. The overall scatter of points about these lines seems to be related largely to the precision of our analyses. For instance, the points for Hole 428 and 428A basalts form an array on the Y-Zr plot (Figure 8) that seems to define a short segment of a variation trend that could be fitted best by a line intersecting the ordinate of this diagram at about $20 \mathrm{ppm}$ Y. Nevertheless, as most of the points in this array fall within a range of $10 \mathrm{ppm} \mathrm{Zr}$ and $4 \mathrm{ppm} \mathrm{Y}$, which is the $2 \sigma$ of our analytical precision, we must be cautious about the validity of this cross-trend.

The scatter of points about the best-fit line on Figure 9 appears substantial because of the inflated scale used for this diagram. The scatter is in fact no larger than that for a segment of similar length within the excellent linear $\mathrm{Ta}$ - Th covariance recorded for the FAMOUS area lavas by Bougault et al. (1979).

For closer consideration of the relationships shown on Figures 6 through 9 we shall use the empirical concept and order of "relative incompatibility"' among minor elements, developed by Bougault et al. (1979), Wood et al. (1979), and Morrison et al. (in press). In Figure 6, the analyses of OCP Ridge and Siqueiros frac- ture zone samples all plot on the side of the line through zero nearer to the axis of the more incompatible element (Ce), while all but one of the EPR sample analyses plot on the other side, confirming the relationship shown in Figure 4. The same tendency for the OCP Ridge and Siqueiros fracture zone samples to have higher ratios of more incompatible to less incompatible elements than those from the EPR is also seen, although less clearly, in Figures 7 and 8. In Figure 9 the OCP Ridge and Siqueiros fracture zone samples show consistently differing $\mathrm{Th} / \mathrm{Ta}$ values and plot on opposite sides of the line, whereas the EPR data straddle it.

It is apparent from Table 3 and Figure 8 that the OCP Ridge samples from Site 428 and those forming the two eruptive units in Hole 422 each have slightly differing average values of $\mathrm{Ti} / \mathrm{Zr}$ and $\mathrm{Y} / \mathrm{Zr}$. Furthermore, the variation of $\mathrm{Ti}-\mathrm{Zr}$ and $\mathrm{Y}-\mathrm{Zr}$ within the eruptive unit sampled by Hole 427, appears to form a pair of short sub-trends on Figure 8 intersecting the Ti and $\mathrm{Y}$ axes.

\section{DISCUSSION OF GEOCHEMISTRY}

We shall discuss the geochemistry of the Leg 54 basalts, as has been outlined here, in terms of three processes: (1) open- or closed-system fractional crystallization - operating to produce the variation observed either within individual eruptive units or between them; (2) variable degree of upper-mantle fusion at the time of magma genesis; and (3) variable upper-mantle composition, demonstrated by variability in the ratios of elements that are not subsequently fractionated - relative to each other - by partial fusion or crystallization processes at spreading axes. We shall not consider magma mixing because our mineralogical and petrographic 
TABLE 3 - Continued

\begin{tabular}{|c|c|c|c|c|c|c|c|c|c|c|c|c|c|c|c|}
\hline $428 \mathrm{~A}-1-2$ & $428 \mathrm{~A}-1-3$ & $428 \AA-1-4$ & $428 \mathrm{~A}-2-1$ & $428 \mathrm{~A}-2-1$ & $428 \mathrm{~A}-3-1$ & $428 \mathrm{~A}-4-2$ & $428 \mathrm{~A}-4-2$ & $428 \mathrm{~A} \cdot 5-1$ & $428 \mathrm{~A}-5-2$ & $428 \mathrm{~A}-6-1$ & $428 \mathrm{~A}-6-1$ & $428 \mathrm{~A}-7-1$ & $428 \mathrm{~A}-7-2$ & $428 \mathrm{~A}-7-2$ & $428 \mathrm{~A}-7-3$ \\
\hline 6 & $3 \mathrm{~A}$ & $3 \mathrm{~B}$ & $2 B$ & 8 & 11 & $1 \mathrm{~A}$ & 7 & 4 & $S A$ & 6 & 14 & $7 \mathrm{~B}$ & 7 & 8 & 1 \\
\hline 51.20 & 51.19 & 50.88 & 51.56 & 50.62 & 49.71 & 50.13 & 50.32 & 49.63 & 50.75 & 50.63 & 50.52 & 50.62 & 50.31 & 50.84 & 50.37 \\
\hline 14.96 & 14.80 & 15.01 & 15.71 & 14.69 & 14.72 & 14.72 & 14.55 & 14.81 & 15.05 & 15.49 & 15.23 & 15.01 & 15.12 & 14.85 & 14.55 \\
\hline 2.59 & 2.79 & 2.18 & 3.15 & 2.58 & 2.98 & 3.13 & 4.52 & 4.48 & 2.61 & 2.61 & 3.32 & 2.48 & 2.66 & 3.27 & 2.42 \\
\hline 7.33 & 7.11 & 7.68 & 5.27 & 7.43 & 6.75 & 6.58 & 6.02 & 5.88 & 6.85 & 6.53 & 6.06 & 7.25 & 6.56 & 6.56 & 6.98 \\
\hline 7.51 & 7.87 & 7.69 & 6.85 & 7.99 & 7.14 & 7.95 & 7.39 & 7.47 & 7.65 & 7.67 & 7.38 & 8.00 & 6.87 & 7.31 & 7.84 \\
\hline 11.93 & 11.89 & 11.95 & 12.38 & 11.73 & 12.14 & 12.48 & 12.14 & 11.79 & 11.77 & 12.22 & 12.51 & 11.84 & 12.86 & 11.74 & 11.54 \\
\hline 2.88 & 2.92 & 2.93 & 3.30 & 2.80 & 2.93 & 2.91 & 2.89 & 3.15 & 2.96 & 2.87 & 2.94 & 2.99 & 2.96 & 2.99 & 2.84 \\
\hline 0.18 & 0.10 & 0.13 & 0.22 & 0.19 & 0.21 & 0.10 & 0.18 & 0.21 & 0.12 & 0.15 & 0.16 & 0.11 & 0.15 & 0.24 & 0.14 \\
\hline 1.52 & 1.50 & 1.50 & 1.58 & 1.48 & 1.49 & 1.46 & 1.50 & 1.51 & 1.49 & 1.45 & 1.48 & 1.48 & 1.54 & 1.41 & 1.47 \\
\hline 0.15 & 0.15 & 0.16 & 0.16 & 0.15 & 0.15 & 0.15 & 0.15 & 0.17 & 0.15 & 0.14 & 0.15 & 0.10 & 0.16 & 0.16 & 0.15 \\
\hline 0.19 & 0.18 & 0.20 & 0.16 & 0.18 & 0.18 & 0.16 & 0.17 & 0.18 & 0.17 & 0.16 & 0.16 & 0.17 & 0.18 & 0.17 & 0.16 \\
\hline 0.38 & 0.45 & 0.33 & 0.30 & 0.43 & 0.55 & 0.80 & 0.59 & 0.83 & 0.52 & 0.67 & 0.55 & 0.47 & 0.35 & 0.48 & 0.56 \\
\hline 0.10 & 0.12 & 0.20 & 0.09 & 0.14 & 0.3 ? & 0.52 & 0.41 & 0.33 & 0.17 & 0.15 & 0.27 & 0.15 & 0.89 & 0.06 & 0.11 \\
\hline 100.92 & 101.07 & 100.84 & 100.73 & 100.41 & 99.32 & 100.89 & 100.83 & 100.44 & 100.26 & 100.74 & 100.73 & 100.67 & 100.61 & 100.08 & 99.13 \\
\hline 1 & 0 & 1 & - & 1 & 2 & 1 & 3 & 4 & 0 & - & 1 & 1 & 1 & 4 & 0 \\
\hline 124 & 130 & 125 & - & 122 & 182 & 234 & 132 & 122 & 125 & - & 127 & 121 & 130 & 125 & 122 \\
\hline 29 & 28 & 28 & - & 26 & 29 & 28 & 28 & 28 & 29 & - & 29 & 28 & 30 & 28 & 26 \\
\hline 98 & 96 & 96 & - & 99 & 91 & 90 & 92 & 91 & 95 & - & 93 & 91 & 97 & 91 & 94 \\
\hline 4 & 5 & 5 & - & 4 & 4 & 4 & 4 & 5 & 5 & - & 4 & 7 & 4 & 5 & 5 \\
\hline - & - & - & - & - & - & - & - & - & - & - & - & - & - & - & - \\
\hline 1.06 & 0.59 & 0.77 & 1.30 & 1.12 & 1.24 & 0.59 & 1.06 & 1.24 & 0.71 & 0.89 & 0.95 & 0.65 & 0.89 & 1.42 & 0.83 \\
\hline 24.37 & 24.71 & 24.79 & 27.92 & 23.69 & 24.79 & 24.62 & 24.46 & 26.66 & 25.05 & 24.29 & 24.88 & 25.30 & 25.05 & 25.30 & 24.03 \\
\hline 27.36 & 26.98 & 27.42 & 27.41 & 26.95 & 26.39 & 26.81 & 26.20 & 25.65 & 27.43 & 28.94 & 27.89 & 27.21 & 27.53 & 26.39 & 26.54 \\
\hline 24.63 & 24.64 & 24.08 & 26.26 & 23.92 & 24.89 & 26.10 & 24.90 & 24.20 & 23.51 & 24.21 & 25.61 & 24.34 & 24.11 & 24.82 & 23.48 \\
\hline 14.19 & 13.97 & 12.83 & 7.53 & 13.74 & 9.74 & 8.48 & 12.03 & 5.34 & 13.37 & 11.30 & 9.56 & 10.12 & 12.96 & 11.64 & 16.23 \\
\hline 3.17 & 3.97 & 4.69 & 4.09 & 4.79 & 5.36 & 7.29 & 5.00 & 10.03 & 3.82 & 4.75 & 5.17 & 6.93 & 2.12 & 4.50 & 0.90 \\
\hline 2.17 & 2.17 & 2.17 & 2.17 & 2.17 & 2.17 & 2.17 & 2.17 & 2.17 & 2.17 & 2.17 & 2.17 & 2.17 & 2.17 & 2.17 & 2.17 \\
\hline 2.89 & 2.85 & 2.85 & 3.00 & 2.81 & 2.83 & 2.77 & 2.85 & 2.87 & 2.83 & 2.75 & 2.81 & 2.81 & 2.92 & 2.68 & 2.79 \\
\hline 0.35 & 0.35 & 0.37 & 0.37 & 0.35 & 0.35 & 0.35 & 0.35 & 0.39 & 0.35 & 0.32 & 0.35 & 0.23 & 0.37 & 0.37 & 0.35 \\
\hline 0.23 & 0.27 & 0.45 & 0.20 & 0.32 & 0.84 & 0.73 & 0.93 & 0.75 & 0.39 & 0.34 & 0.61 & 0.34 & 2.02 & 0.14 & 0.25 \\
\hline
\end{tabular}

studies (Thompson and Humphris, this volume) give no persuasive evidence that this process has occurred during the evolution of the Leg 54 magmas.

\section{Fractional Crystallization}

The Siqueiros fracture zone eruptive unit intersected by Hole 427 is the only part of the Leg 54 basalt suite which contains phenocrysts large enough $(<2 \mathrm{~mm})$ to allow the possibility of intraflow chemical variation, as a result of local fractionation of its phenocryst phases, Ca-rich clinopyroxene, and plagioclase. Calculations, shown in Table 8, indicate that crystallization of 5.7 per cent plagioclase, and 4.1 per cent clinopyroxene phenocrysts can account for the variation observed in the Hole 427 basalts. Separation of clinopyroxene and plagioclase (without olivine) during the final stages of evolution of the Hole 427 basalts may also explain why they are somewhat poorer in normative $d i$ than other Leg 54 lavas.

The close fits of the Leg 54 data to lines radiating from zero on Figures 6 through 8 show clearly that closed-system fractional crystallization is by far the dominant process in the evolution of these magmas to their erupted compositions. Low pressure, open-system fractionation involving the separation of multiphase cotectic solid assemblages (including pyroxene) - as envisaged by O'Hara (1977) and Bryan et al. (1979) would affect the ratios of such element pairs as $\mathrm{Ce} / \mathrm{Yb}$, $\mathrm{Th} / \mathrm{Tb}, \mathrm{Zr} / \mathrm{Ti}$, and $\mathrm{Zr} / \mathrm{Y}$, producing curved trends rather than the straight lines seen on Figures 6 through 8 .

Published geochemical data for basalts from various parts of the MAR, sampled during DSDP Legs 37, 45, 46, 49, and the FAMOUS project, are plotted on Figures 6 through 8 . The $22^{\circ} \mathrm{N}$ data fit closely to linear trends, showing slightly lower ratios of $\mathrm{Ce} / \mathrm{Yb}$ and $\mathrm{Th} / \mathrm{Tb}$ than Leg 54 samples. Flower et al. (1978) and Bougault et al. (1979) have proposed that fractional crystallization was the predominant mechanism generating the chemical diversity of the $22^{\circ} \mathrm{N}$ lavas. Data for the MAR basalts at $36^{\circ} \mathrm{N}$ and $63^{\circ} \mathrm{N}$ on Figures 6 and 7 may be fitted either by curves passing through zero or by linear trends intersecting the less incompatible element axes $(\mathrm{Yb}$ and $\mathrm{Tb})$ of these plots. The $36^{\circ} \mathrm{N}$ variation has been attributed to variably incremental partial fusion of initially chemically homogeneous mantle, with inefficient magma extraction at each stage (Langmuir et al., 1977; Wood et al., 1979). The main control on the compositions of the $63^{\circ} \mathrm{N}$ samples was deduced by Wood et al. (1979) to be upper-mantle chemical inhomogeneity, predating the MAR melting event.

The data in Table 9 add further details to a fractionation model for Leg 54 lavas. Incompatible element abundances in the most primitive and most evolved compositions of the suite are listed, together with the ratio of these values $C / C_{o}-$ the enrichment factor for each element. It should be emphasized that this Table gives only an approximate representation of incompatible element behavior in the Leg 54 suite. Ideally, several analyses should be averaged to derive the primitive and evolved end members, whereas only two are available to us in each case. Nevertheless, the enrichment factors for $\mathrm{Ce}, \mathrm{Nd}, \mathrm{Tb}, \mathrm{Yb}, \mathrm{Y}$, and $\mathrm{Hf}$ are all very similar in this suite and indicate that the extent of solidification required to produce the evolved form from the primitive end member is just under 50 per cent. The slightly lower value of $C / C_{o}$ calculated for $\mathrm{TiO}_{2}$ could be attributed to a substantial pyroxene fraction among the separating solids. However, similar $C / C_{o}$ values for $\mathrm{Zr}$ and $\mathrm{P}_{2} \mathrm{O}_{5}$ 
TABLE 4

Analyses of Basalts from the Siqueiros Fracture Zone

\begin{tabular}{|c|c|c|c|c|c|c|c|c|c|c|c|c|}
\hline & $\begin{array}{l}\text { Hole-Core- } \\
\text { Section }\end{array}$ & $427-9-1$ & $427-9-2$ & $427-9-2$ & $427-9-2$ & $427-9-3$ & $427-9-4$ & $427-10-1$ & $427-10-2$ & $427-10-3$ & $427-10-4$ & $427-11-1$ \\
\hline wt.\% & Piece & 9 & 4 & 5 & $9 \mathrm{~A}$ & $6 \mathrm{~B}$ & $4 \mathrm{~A}$ & 1 & $2 \mathrm{~A}$ & 3 & $1 \mathrm{H}$ & 3 \\
\hline $\mathrm{SiO}_{2}$ & & 49.03 & 50.43 & 50.41 & 50.26 & 49.18 & 49.80 & 49.78 & 49.83 & 50.32 & 50.72 & 50.64 \\
\hline $\mathrm{Al}_{2} \mathrm{O}_{3}$ & & 13.30 & 13.65 & 13.89 & 13.63 & 13.25 & 13.44 & 13.90 & 13.81 & 13.78 & 13.72 & 14.23 \\
\hline $\mathrm{Fe}_{2} \mathrm{O}_{3}$ & & 4.50 & 4.18 & 4.02 & 4.06 & 3.59 & 3.66 & 3.92 & 3.99 & 4.08 & 3.99 & 3.02 \\
\hline $\mathrm{FeO}$ & & 8.30 & 8.73 & 8.59 & 8.90 & 9.13 & 9.38 & 8.30 & 8.53 & 8.80 & 8.46 & 8.73 \\
\hline $\mathrm{MgO}$ & & 6.48 & 6.46 & 6.49 & 6.71 & 6.41 & 6.65 & 6.42 & 6.58 & 6.58 & 6.80 & 6.72 \\
\hline $\mathrm{CaO}$ & & 10.60 & 10.16 & 10.18 & 10.22 & 10.51 & 9.82 & 10.68 & 10.26 & 10.42 & 9.98 & 10.95 \\
\hline $\mathrm{Na}_{2} \mathrm{O}$ & & 3.18 & 3.14 & 3.15 & 3.09 & 3.03 & 3.13 & 3.36 & 3.28 & 3.12 & 3.17 & 3.15 \\
\hline $\mathrm{K}_{2} \mathrm{O}$ & & 0.12 & 0.17 & 0.19 & 0.20 & 0.21 & 0.22 & 0.10 & 0.15 & 0.17 & 0.14 & 0.11 \\
\hline $\mathrm{TiO}_{2}$ & & 2.43 & 2.48 & 2.46 & 2.49 & 2.46 & 2.51 & 2.62 & 2.51 & 2.49 & 2.39 & 2.12 \\
\hline $\mathrm{P}_{2} \mathrm{O}_{5}$ & & 0.22 & 0.22 & 0.23 & 0.23 & 0.23 & 0.32 & 0.19 & 0.24 & 0.22 & 0.22 & 0.22 \\
\hline $\mathrm{MnO}$ & & 0.20 & 0.21 & 0.20 & 0.20 & 0.20 & 0.20 & 0.17 & 0.22 & 0.26 & 0.18 & 0.21 \\
\hline $\mathrm{H}_{2} \mathrm{O}^{+}$ & & 0.70 & 0.73 & 0.55 & 0.52 & 0.62 & 0.61 & 0.47 & 0.53 & 0.50 & 0.78 & 0.71 \\
\hline $\mathrm{CO}_{2}$ & & 0.63 & 0.19 & 0.18 & 0.18 & 0.70 & 0.04 & 0.06 & 0.27 & 0.25 & 0.03 & 0.03 \\
\hline Total & & 99.69 & 100.75 & 100.54 & 100.69 & 99.52 & 99.78 & 99.97 & 100.20 & 100.99 & 100.58 & 100.84 \\
\hline
\end{tabular}

Selected trace elements in ppm

\begin{tabular}{|c|c|c|c|c|c|c|c|c|c|c|c|}
\hline $\mathrm{Rb}$ & 0 & 1 & 0 & 1 & 1 & 0 & 0 & 0 & 1 & 0 & 0 \\
\hline $\mathrm{Sr}$ & 210 & 119 & 120 & 116 & 164 & 119 & 126 & 123 & 117 & 118 & 118 \\
\hline $\mathrm{Y}$ & 43 & 47 & 47 & 45 & 47 & 50 & 42 & 47 & 48 & 45 & 43 \\
\hline $\mathrm{Zr}_{\mathrm{r}}$ & 152 & 161 & 166 & 163 & 164 & 170 & 140 & 174 & 169 & 164 & 140 \\
\hline $\mathrm{Nb}$ & 4 & 6 & 6 & 6 & 6 & 6 & 6 & 7 & 8 & 6 & 6 \\
\hline
\end{tabular}

C.I.P.W. Norm

\begin{tabular}{|c|c|c|c|c|c|c|c|c|c|c|c|}
\hline Q & - & - & - & - & - & - & $\overline{-}$ & - & - & - & $\overline{0}$ \\
\hline Or & 0.71 & 1.00 & 1.12 & 1.18 & 1.24 & 1.30 & 0.59 & 0.89 & 1.00 & 0.83 & 0.65 \\
\hline $\mathrm{Ab}$ & 26.91 & 26.57 & 26.66 & 26.15 & 25.64 & 26.49 & 28.43 & 27.76 & 26.40 & 26.82 & 26.66 \\
\hline An & 21.66 & 22.65 & 23.20 & 22.73 & 21.93 & 21.97 & 22.55 & 22.52 & 23.09 & 22.79 & 24.36 \\
\hline $\mathrm{Di}$ & 21.07 & 20.76 & 20.36 & 20.91 & 20.06 & 20.16 & 23.74 & 20.71 & 21.13 & 20.67 & 23.32 \\
\hline $\mathrm{Hy}$ & 15.64 & 19.86 & 19.24 & 18.68 & 19.50 & 18.18 & 10.55 & 15.23 & 18.31 & 20.05 & 14.83 \\
\hline $\mathrm{Ol}$ & 3.97 & 1.08 & 1.36 & 2.42 & 1.35 & 3.08 & 5.67 & 4.21 & 2.23 & 1.09 & 3.39 \\
\hline $\mathrm{Mt}$ & 2.17 & 2.17 & 2.17 & 2.17 & 2.17 & 2.17 & 2.17 & 2.17 & 2.17 & 2.17 & 2.17 \\
\hline II & 4.62 & 4.71 & 4.67 & 4.73 & 4.67 & 4.77 & 4.98 & 4.77 & 4.73 & 4.54 & 4.03 \\
\hline Ap & 0.51 & 0.51 & 0.53 & 0.53 & 0.53 & 0.74 & 0.44 & 0.56 & 0.51 & 0.51 & 0.51 \\
\hline CC & 1.43 & 0.43 & 0.41 & 0.41 & 1.59 & 0.09 & 0.14 & 0.61 & 0.57 & 0.07 & 0.07 \\
\hline
\end{tabular}

TABLE 5

Microprobe Analyses (wt. \%) of Two Leg 54 Glasses $^{\mathrm{a}}$

\begin{tabular}{lcccc}
\hline & $\begin{array}{c}\text { Sample } \\
429 \mathrm{~A}-2-1 \\
\text { (Piece 4A) }\end{array}$ & $\begin{array}{c}\text { Sample } \\
420-16-1 \\
\text { (Piece 1) }\end{array}$ & $\begin{array}{c}\text { USNM } \\
113716\end{array}$ & $2 \sigma$ \\
\hline & (6 points) & $(5$ points) & $(10$ points) & \\
$\mathrm{SiO}_{2}$ & 50.52 & 51.12 & $51.70(51.52)$ & 0.46 \\
$\mathrm{Al}_{2} \mathrm{O}_{3}$ & 15.17 & 13.81 & $15.13(15.39)$ & 0.26 \\
$\mathrm{Cr}_{2} \mathrm{O}_{3}$ & 0.08 & - & - & - \\
$\mathrm{FeO}^{*}$ & 9.23 & 11.80 & $9.24(9.13)$ & - \\
$\mathrm{MnO}$ & 0.08 & 0.21 & $0.13(0.17)$ & 0.20 \\
$\mathrm{MgO}$ & 8.05 & 6.64 & $7.91(8.21)$ & 0.16 \\
$\mathrm{NiO}$ & - & - & - & - \\
$\mathrm{CaO}$ & 12.65 & 11.40 & $11.39(11.31)$ & 0.13 \\
$\mathrm{Na}_{2} \mathrm{O}$ & 2.85 & 2.88 & $2.78(2.48)$ & 0.20 \\
$\mathrm{~K}_{2} \mathrm{O}$ & - & 0.10 & trc $(0.09)$ & - \\
$\mathrm{TiO}_{2}$ & 1.24 & 2.03 & $1.35(1.30)$ & 0.16 \\
$\mathrm{Total}$ & 99.87 & 99.99 & 99.63 & \\
\hline
\end{tabular}

${ }^{a}$ Data obtained on a Link energy dispersive system fitted to a Cambridge Instruments Microscan V microprobe.

Operating conditions: accelerating voltage: $15 \mathrm{kV}$ sample current: $\quad 0.01 \mu \mathrm{A}$ counting time: $\quad 100 \mathrm{~s}$

$\mathrm{b}_{\text {Wet chemical analy sis (Smithsonian Institution). }}$

$\mathrm{c}_{\mathrm{tr}}=$ trace amount. underline the need for caution in constructing detailed quantitative models. The much lower $C / C_{o}$ values for $\mathrm{Nb}, \mathrm{Ta}$, and $\mathrm{Th}$ in Table 9 will be subsequently discussed in the context of mantle heterogeneity.

\section{Variable Degree of Partial Fusion and Mantle Inhomogeneity}

Although the contrast between the trends of MAR $36^{\circ} \mathrm{N}$ and $63^{\circ} \mathrm{N}$ data and the distribution of Leg 54 data on Figures 6 and 7 confirms our conclusion that mantle inhomogeneity and variable partial fusion were not important factors during the genesis of the latter, it does not mean that they can be neglected entirely. We have already noted above that $(\mathrm{Ce} / \mathrm{Yb})_{\mathrm{N}}$ is slightly lower in the EPR, than the OCP Ridge and Siqueiros fracture zone samples (Figure 5), and also that there are signs of variations in $\mathrm{Tb} / \mathrm{Th}, \mathrm{Y} / \mathrm{Zr}$, and $\mathrm{Ti} / \mathrm{Zr}$ within the $\mathrm{OCP}$ Ridge suite (Figures 7 and 8). If open-system fractionation is rejected as a cause, through lack of appropriate mineralogical evidence (Thompson and Humphris, this volume), the variations of $(\mathrm{Ce} / \mathrm{Yb})_{\mathrm{N}}$ and similar ratios must result from mantle inhomogeneity or variable partial fusion during magma genesis. These processes are difficult to investigate on diagrams such as Figures 6 to 


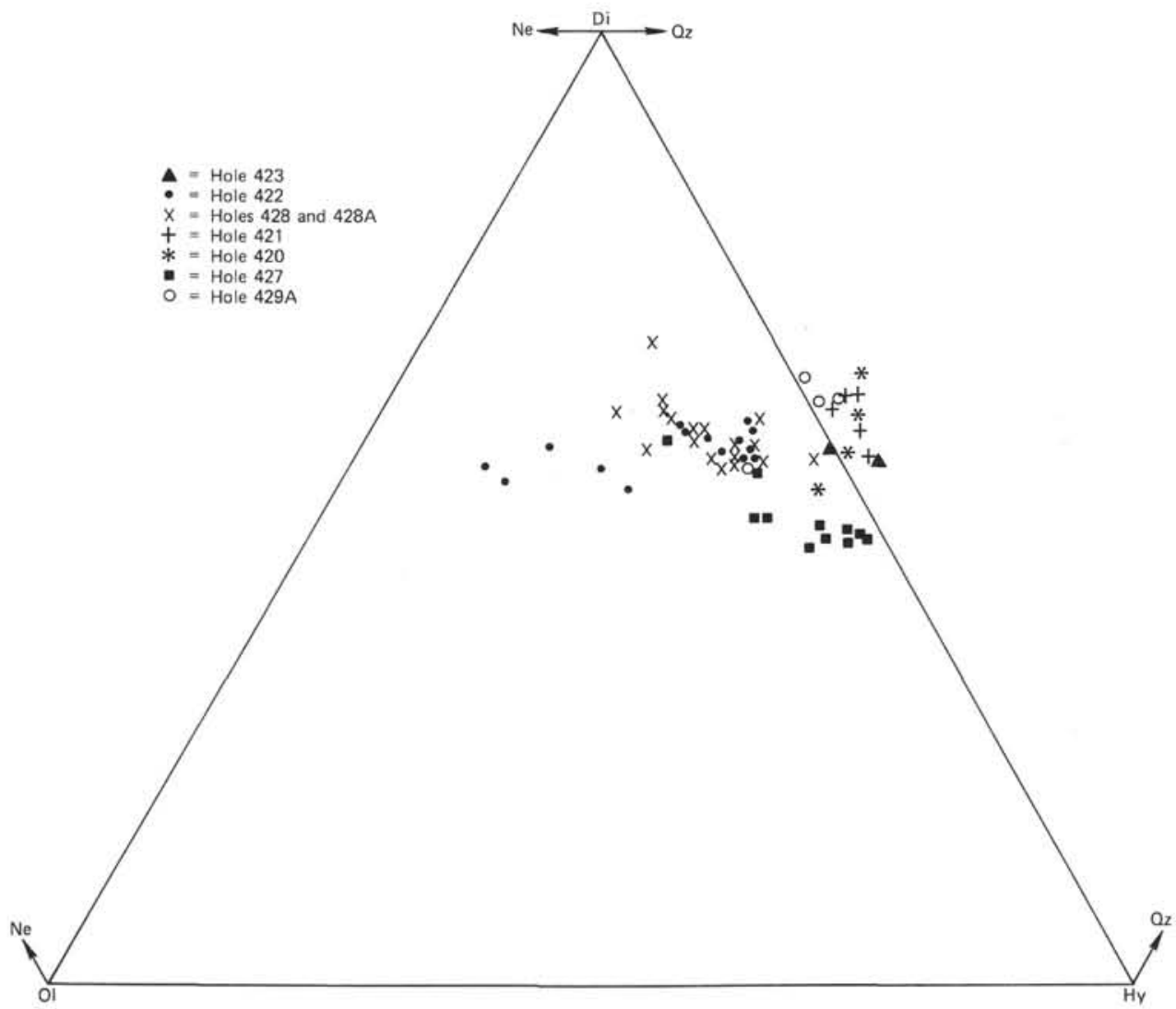

Figure 2. Normative diagram for basalts from the East Pacific Rise, OCP Ridge, and the Siqueiros fracture zone.

TABLE 6

Compositions of Leg 54 Basalts Compared with Other Reported Ocean Ridge Basalt Analyses

\begin{tabular}{|c|c|c|c|c|c|c|c|c|c|c|c|}
\hline wt. \% & 1 & $\begin{array}{c}\text { East } \mathrm{Pa} \\
\quad 2\end{array}$ & $\begin{array}{c}\text { cific Rise } \\
3\end{array}$ & 4 & $\begin{array}{c}\mathrm{EPR} \\
5\end{array}$ & $\begin{array}{c}\text { Leg } 54 \\
\text { OCPR } \\
6\end{array}$ & $\begin{array}{c}\text { SFZ } \\
7\end{array}$ & $\begin{array}{c}\text { SFZ } \\
8\end{array}$ & $\begin{array}{c}\text { Leg } 34 \\
\text { Nazca } \\
9\end{array}$ & $\begin{array}{c}\text { MAR } \\
10\end{array}$ & $\begin{array}{c}\text { All Oceanic } \\
\text { Ridges } \\
11\end{array}$ \\
\hline $\mathrm{SiO}_{2}$ & 50.40 & 49.57 & 49.65 & 50.00 & 51.30 & 50.66 & 50.04 & 49.34 & 51.60 & $49.21 \pm 0.74$ & $49.61 \pm 0.72$ \\
\hline $\mathrm{Al}_{2} \mathrm{O}_{3}$ & 14.30 & 15.44 & 16.19 & 14.07 & 14.56 & 15.13 & 13.69 & 14.92 & 14.59 & $15.81 \pm 1.50$ & $16.01 \pm 0.85$ \\
\hline $\mathrm{FeO} *$ & 10.00 & 9.61 & 9.06 & 11.93 & 10.84 & 10.27 & 13.57 & 10.05 & 11.07 & $9.29 \pm 1.25$ & $11.49 \pm 1.27$ \\
\hline $\mathrm{MgO}$ & 7.10 & 7.56 & 8.37 & 8.03 & 6.63 & 7.41 & 6.57 & 8.46 & 7.14 & $8.53 \pm 1.98$ & $7.84 \pm 0.90$ \\
\hline $\mathrm{CaO}$ & 12.30 & 11.49 & 12.01 & 11.69 & 11.29 & 11.99 & 10.34 & 11.89 & 10.77 & $11.14 \pm 0.78$ & $11.32 \pm 0.64$ \\
\hline $\mathrm{Na}_{2} \mathrm{O}$ & 2.78 & 3.10 & 2.75 & 3.19 & 3.00 & 2.94 & 3.16 & 2.95 & 2.66 & $2.71 \pm 0.19$ & $2.76 \pm 0.25$ \\
\hline $\mathrm{K}_{2} \mathrm{O}$ & 0.12 & 0.28 & 0.11 & 0.18 & 0.33 & 0.17 & 0.16 & 0.12 & 0.07 & $0.26 \pm 0.17$ & $0.22 \pm 0.12$ \\
\hline $\mathrm{TiO}_{2}$ & 1.60 & 1.80 & 1.37 & 1.64 & 2.79 & 1.48 & 2.45 & 1.40 & 1.82 & $1.39 \pm 0.28$ & $1.43 \pm 0.29$ \\
\hline $\mathrm{MnO}$ & - & 0.17 & 0.18 & 0.19 & 0.20 & 0.17 & 0.23 & 0.19 & 0.18 & $0.16 \pm 0.03$ & $0.18 \pm 0.04$ \\
\hline $\begin{array}{l}\mathrm{FeO} * / \mathrm{MgO} \\
(\mathrm{ppm})\end{array}$ & 1.41 & 1.27 & 1.08 & 1.49 & 1.64 & 1.39 & 2.07 & 1.19 & 1.55 & 1.09 & 1.46 \\
\hline $\mathrm{Rb}$ & - & - & - & - & 2 & 1 & 0 & - & - & - & - \\
\hline $\mathrm{Sr}$ & 125 & - & 110 & - & 127 & 140 & 131 & - & 97 & $123 \pm 46$ & - \\
\hline $\mathrm{Y}$ & - & - & 42 & - & 43 & 28 & 46 & - & 50 & $43 \pm 12$ & - \\
\hline $\mathrm{Zr}$ & - & - & 78 & - & 138 & 96 & 160 & - & 137 & $100 \pm 42$ & - \\
\hline $\mathrm{Nb}$ & - & - & - & - & 5 & 6 & 6 & - & - & - & - \\
\hline
\end{tabular}

Notes: $1=$ Kay et al., $1970 ; 2=$ Bonatti, $1968 ; 3=$ Engel et al., 1965; $4=$ Batiza et al., $1977 ; 5=$ Leg 54 basalts (this study); 6 = Leg 54 basalts (this study); $7=$ Leg 54 basalts (this study); $8=$ Siqueiros fracture zone basalts (Batiza et al., 1977); $9=$ Nazca Plate basalts (Thompson et al., 1976); $10=$ average of 33 basalts (Melson et al., 1968);11= average of 94 basalts (Cann, 1971).

8 , because all the points must be projected by unknown amounts towards zero - to remove the effects of postgenesis fractionation - before trends among primary magmas may be assessed.
It is generally agreed that suites of ocean-floor basalts strongly depleted in the incompatible elements, such as the Leg 54 samples, were produced by a further melting increment of upper mantle which had previous- 
S. E. HUMPHRIS, R. N. THOMPSON, I. L. GIBSON, G. F. MARINER
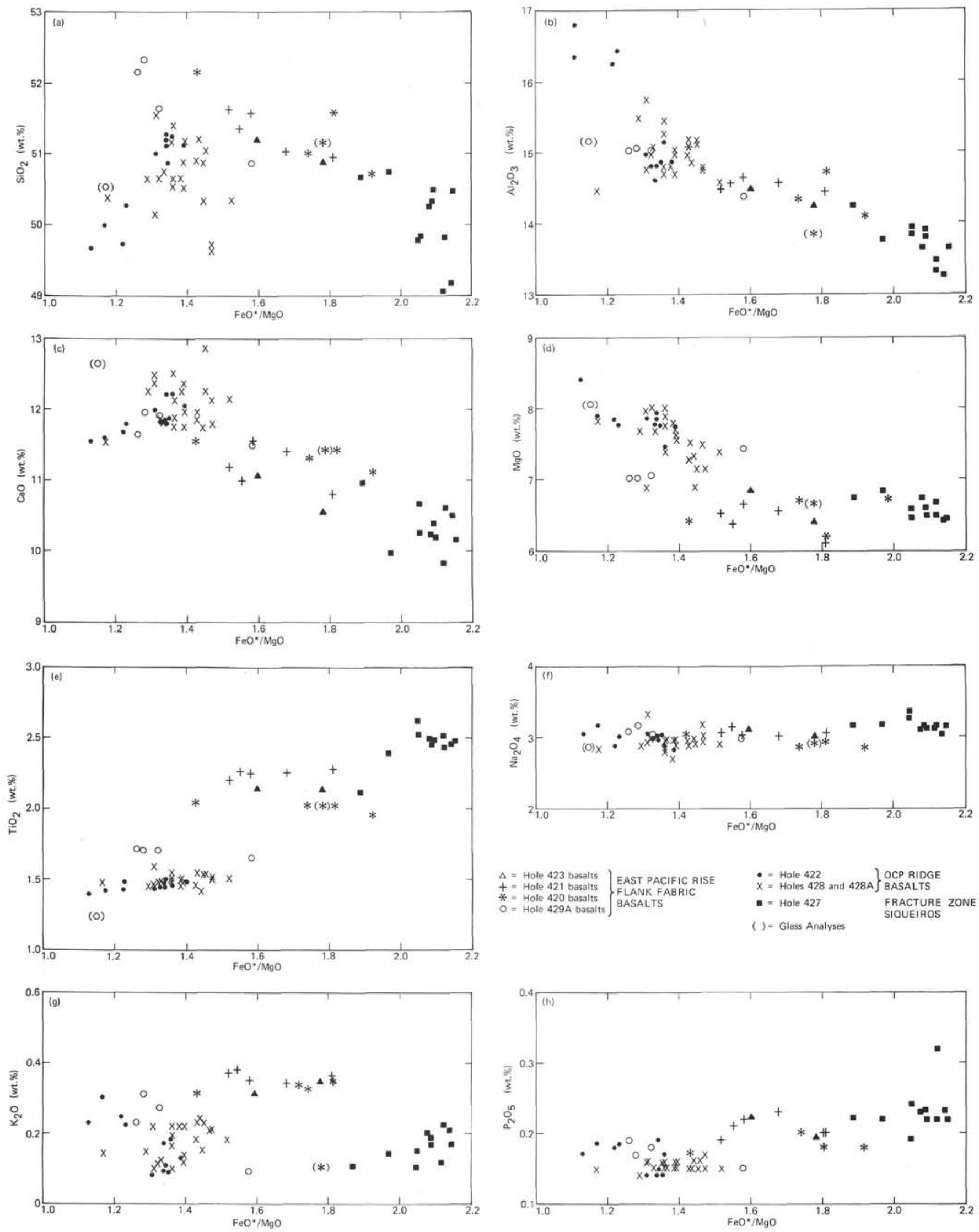

Figure 3. (a-h) Major oxides plotted against the $\mathrm{FeO} * / \mathrm{MgO}$ ratio.

644 
ly lost a fraction rich in incompatible elements. We agree with Wood et al. (1979) that the available geochemical data for MAR lavas favor the hypothesis that this previously extracted fraction was a basaltic melt. The variations in $(\mathrm{Ce} / \mathrm{Yb})_{\mathrm{N}}$ and similar ratios of moreto-less incompatible elements in the magma of the rocks sampled by Leg 54 were therefore probably inherited beneath the region, and relate to variable partial fusion during a previous (i.e., pre-EPR) melting event. Measurements of radiogenic $\mathrm{Sr}, \mathrm{Nd}$, and $\mathrm{Pb}$ isotopes in these samples are required to confirm this point.

Bougault et al. (1979) have shown that the ratios among the ultra incompatible elements $\mathrm{La}, \mathrm{Nb}, \mathrm{Ta}$, and Th are not measurably affected by episodes of uppermantle fusion involving the production of a basaltic melt. The grouping of points for OCP Ridge and Siqueiros fracture zone samples around two slightly different ratios of $\mathrm{Th} / \mathrm{Ta}$ on Figure 9 is therefore suggestive of local, upper-mantle chemical heterogeneity beneath the area, of a type which cannot be explained by postulating previous episodes of basaltic magma extraction. Obviously further high-precision determinations of $\mathrm{La}, \mathrm{Nb}, \mathrm{Ta}$, and $\mathrm{Th}$ in Leg 54 lavas are needed to investigate this point. Meanwhile, the anomalous values of $C / C_{o}$ for $\mathrm{Nb}, \mathrm{Ta}$, and Th in Table 9 are tentatively ascribed to the same local mantle heterogeneity in the abundance of these elements.

\section{EVOLUTION OF THE MAGMAS}

Rosendahl et al. (1976) and Orcutt et al. (1976) have provided evidence of a wedge-shaped, low-velocity zone beneath the EPR at a depth of 2 to $6 \mathrm{~km}$. Rosendahl (1976) has suggested that this zone may represent a shallow magma chamber. Our mineralogical and petrographic data (Thompson and Humphris, this volume) may be used to reconstruct the crystallization history of the Leg 54 basalts during the last few kilometers of their rise to the surface. The phenocrysts in these lavas show that, within the upper part of Layer 3 of the oceanic crust, they were precipitating plagioclase-dominated assemblages comprising bytownite alone or accompanied, in some cases, by Ca-rich clinopyroxene (in more evolved magmas), or $\mathrm{Cr}-\mathrm{Al}$ spinel (in more primitive magmas). As the magmas presumably originated from a peridotite upper mantle, they must inevitably have fractionated olivine throughout the earlier stages of their rise, although this appears largely to have ceased by the time the liquids reached the top of Layer 3 . The causes of the prominent re-appearance of olivine in the more magnesian magmas, as a component of rapidly formed glomerophyric clusters during their final rise to the surface, are discussed by Thompson and Humphris (this volume).

The geochemical data we have presented above are compatible with a generalized model of fractional crystallization of plagioclase and ferromagnesian minerals as the dominant controlling process throughout the evolution of the suite of basalts sampled during Leg 54. The importance of plagioclase separation is evident from the $\mathrm{Al}_{2} \mathrm{O}_{3}-\mathrm{FeO}^{*} / \mathrm{MgO}$ plot (Figure $3 \mathrm{~b}$ ) and confirmed by the development of negative Eu anomalies in the REE patterns of the more evolved lavas. Determination of the ratio of olivine to pyroxene in the separating solids is complicated by evidence for primary chemical variation in the magmas. This has been demonstrated in terms of variations in some incompatible-element ratios and also the range of $\mathrm{TiO}_{2}$ to be seen at fixed values of $\mathrm{FeO} *$ / $\mathrm{MgO}$ in Figure $3 \mathrm{e}$. This type of variation, especially in $\mathrm{TiO}_{2}$, blurs any attempt to quantify the overall fractionation model to the point where olivine/pyroxene ratios in the precipitates may be determined with certainty.

\section{Origin of the OCP Ridge Magmas}

The morphology of the OCP Ridge (Figure 1) clearly implies that this is a volcanic feature, postdating the EPR flank fabric basalts. This hypothesis is supported, to some extent, by the stratigraphy in the lower part of Hole 422. The whole OCP Ridge is reversely magnetized and appears to have been formed over a very short period.

We envisage two possible mechanisms whereby the substantial volume of basalt forming the OCP Ridge came to be extruded.

1) The magmas have been generated along a linear zone within the upper mantle immediately beneath the Ridge. Shearing - superimposed on the adiabatic rise - and partial fusion of mantle material could provide additional energy for melt extraction, thereby explaining why more magma was extruded along the OCP Ridge.

2) The magmas have originated and evolved beneath the EPR, migrating laterally within the crust to the $\mathrm{OCP}$ Ridge immediately before their extrusion.

At first sight the primary geochemical differences between the lavas of the EPR and OCP Ridge provide strong evidence that the magmas supplying these units came from separate upper-mantle sources. Nevertheless, we re-emphasize that, although these primary differences are present, they are smaller than those characterizing the various eruptive units within many individual holes drilled during the DSDP. Much more extensive sampling than was achieved during Leg 54 will be required to confirm whether the OCP Ridge basalts all show primary geochemical features outside the range of those characterizing the magmas produced along the adjacent segment of the EPR during the past few million years.

If the pre-eruption crystallization histories of the EPR and OCP Ridge basalts - based on petrography and microprobe mineralogy (Thompson and Humphris, this volume) - are compared, it is the similarities rather than the differences between these two groups of lavas which are outstanding. The complex crystallization history of the EPR magmas during their uprise through the upper oceanic crust fits closely to the current geophysical model of this spreading axis (Rosendahl, 1976; Thompson and Humphris, this volume). It is very hard to see how the complex controls on crystallization, which demonstrably operate beneath the EPR, could be reproduced precisely within the entirely different tectonic environment of an off-spreading axis shear belt. 
S. E. HUMPHRIS, R. N. THOMPSON, I. L. GIBSON, G. F. MARRINER

TABLE 7

Rare-Earth Element Analyses of Selected Samples by Instrumental Neutron Activation Analysis (ppm)

\begin{tabular}{|c|c|c|c|c|c|c|c|c|c|c|}
\hline & $\begin{array}{l}\text { Hole-Core- } \\
\text { Section }\end{array}$ & $423-5, \mathrm{CC}$ & $422-7-1$ & $422-8-5$ & $428 \mathrm{~A}-1-1$ & $428 \mathrm{~A}-1-3$ & $428 \mathrm{~A}-2-1$ & $428 \mathrm{~A}-4-2$ & $428 \mathrm{~A}-5-2$ & $428 \mathrm{~A}-7-1$ \\
\hline Elements & Piece & 1 & 7B & 8 & 10 & $3 \mathrm{~A}$ & 8 & $1 \mathrm{~A}$ & $5 \mathrm{~A}$ & 7B \\
\hline $\mathrm{Ce}$ & & 17.01 & 10.79 & 10.98 & 11.68 & 10.96 & 10.13 & 10.16 & 10.73 & 11.67 \\
\hline $\mathrm{Nd}$ & & 16.27 & - & 9.97 & 9.81 & - & 9.20 & 9.95 & 9.96 & 10.00 \\
\hline $\mathrm{Eu}$ & & 1.97 & 1.37 & 1.36 & 1.36 & 1.32 & 1.20 & 1.23 & 1.30 & 1.36 \\
\hline $\mathrm{Gd}$ & & - & 4.60 & 5.05 & 4.59 & 4.55 & - & 4.65 & - & - \\
\hline $\mathrm{Tb}$ & & 1.38 & 0.83 & 0.82 & 0.84 & 0.83 & 0.77 & 0.77 & 0.82 & 0.84 \\
\hline $\mathrm{Tm}$ & & 0.90 & 0.55 & 0.48 & 0.53 & 0.50 & 0.49 & 0.45 & 0.53 & 0.51 \\
\hline $\mathrm{Yb}$ & & 5.47 & 3.19 & 3.09 & 3.28 & 3.13 & 2.87 & 2.97 & 3.05 & 3.19 \\
\hline Th & & - & 0.22 & 0.24 & 0.34 & - & 0.28 & 0.31 & 0.32 & 0.39 \\
\hline $\mathrm{Ta}$ & & 0.71 & 0.45 & 0.45 & - & 0.51 & 0.47 & 0.53 & 0.59 & - \\
\hline $\mathrm{Sm}$ & & 5.87 & 3.74 & 3.79 & 3.65 & 3.78 & 3.37 & 4.31 & 3.48 & 3.68 \\
\hline $\mathrm{Hf}$ & & 4.00 & 2.57 & 2.51 & 2.57 & 2.43 & 2.22 & 2.24 & 2.38 & 2.50 \\
\hline$(\mathrm{Ce} / \mathrm{Yb})_{\mathrm{N}}$ & & 0.79 & 0.86 & 0.90 & 0.91 & 0.89 & 0.89 & 0.87 & 0.89 & 0.93 \\
\hline $\mathrm{Ta} / \mathrm{Hf}$ & & 0.18 & 0.18 & 0.18 & - & 0.21 & 0.21 & 0.24 & 0.25 & - \\
\hline
\end{tabular}

aMean of three determinations.
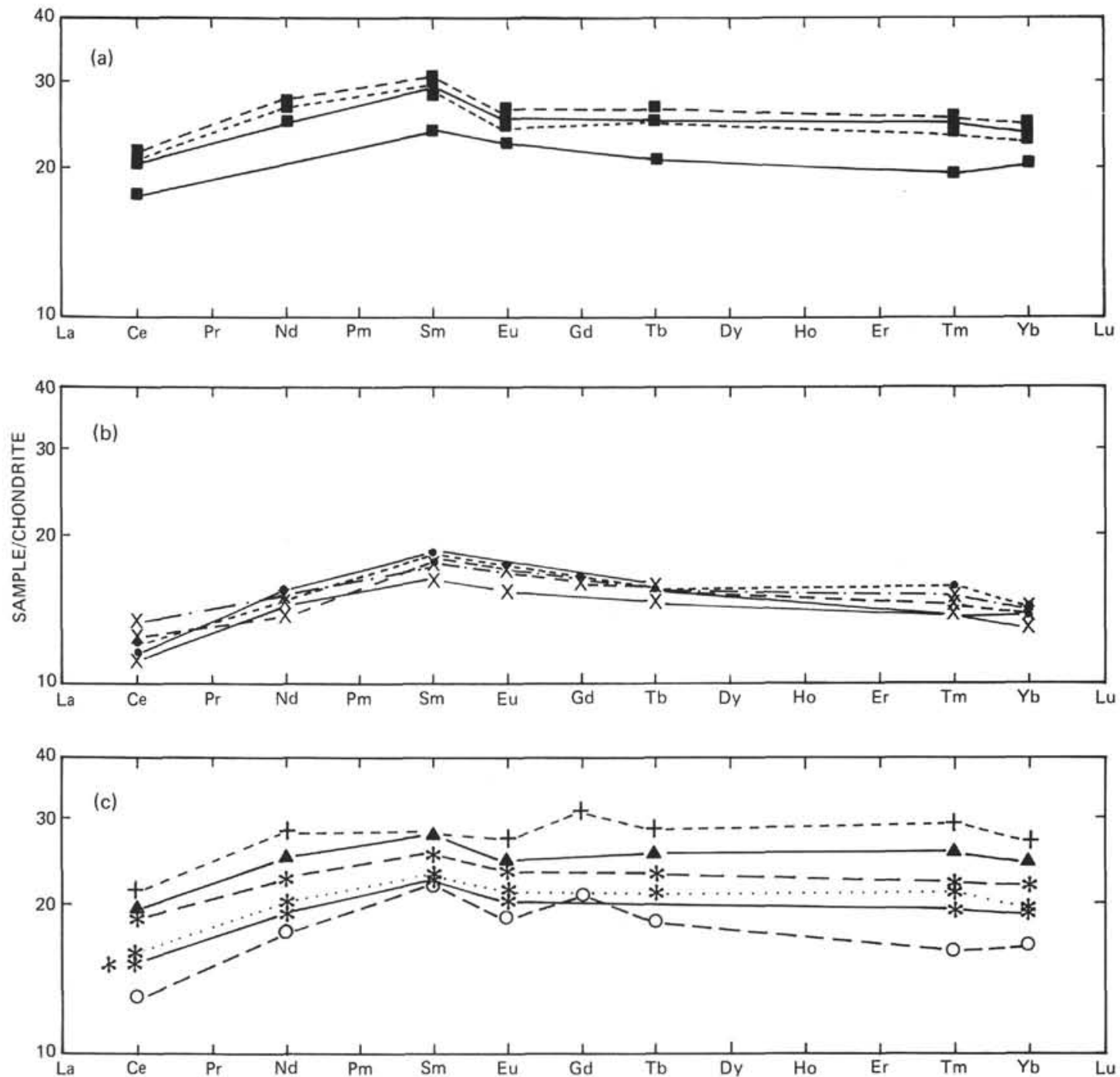

Figure 4. Chondrite-normalized REE patterns for representative basalts from (a) the Siqueiros fracture zone, (b) OCP Ridge, and (c) East Pacific Rise. 
TABLE 7 - Continued

\begin{tabular}{ccccccccccc}
\hline $420-13, \mathrm{CC}$ & $420-14-1$ & $420-14-1$ & $427-9-2$ & $427-9-4$ & $427-10-1$ & $427-10-4$ & $429 \mathrm{~A}-3-1$ & $421-4-2$ & Standard $^{\mathrm{a}}$ \\
& & & & & & & & & & \\
1 & 2 & 8 & 4 & $4 \mathrm{~A}$ & 1 & $1 \mathrm{H}$ & $7 \mathrm{~B}$ & $5 \mathrm{~B}$ & BOB-1 \\
\hline 13.83 & 16.28 & 13.63 & 17.76 & 18.32 & 15.34 & 17.94 & 11.24 & 18.49 & 13.32 \\
13.20 & 14.47 & 12.93 & 15.60 & 17.16 & - & 16.59 & 11.19 & 17.94 & 11.12 \\
1.62 & 1.82 & 1.64 & 1.94 & 2.01 & 1.72 & 1.91 & 1.48 & 2.12 & 1.28 \\
- & - & - & - & - & - & - & 5.92 & 8.99 & 4.46 \\
1.13 & 1.23 & 1.07 & 1.30 & 1.37 & 1.08 & 1.30 & 0.97 & 1.51 & 0.73 \\
- & 0.75 & 0.69 & 0.84 & 0.88 & 0.66 & 0.80 & 0.55 & 1.02 & 0.44 \\
4.37 & 4.94 & 4.34 & 5.17 & 5.37 & 4.54 & 4.99 & 3.71 & 5.97 & 2.70 \\
0.30 & - & 0.33 & 0.44 & 0.42 & 0.40 & 0.46 & 0.31 & 0.36 & 0.51 \\
0.50 & 0.68 & 0.46 & 0.61 & 0.55 & 0.54 & 0.56 & 0.40 & 0.74 & 0.55 \\
4.83 & 5.29 & 4.73 & 5.90 & 6.13 & 4.89 & 5.81 & 4.72 & - & 3.56 \\
3.27 & 3.87 & 3.38 & 4.34 & 4.27 & 3.68 & 4.25 & 2.71 & 4.25 & 2.48 \\
0.80 & 0.84 & 0.80 & 0.87 & 0.87 & 0.86 & 0.91 & 0.77 & 0.79 & 1.25 \\
0.15 & 0.17 & 0.14 & 0.14 & 0.13 & 0.15 & 0.13 & 0.15 & 0.17 & 0.22 \\
\hline
\end{tabular}

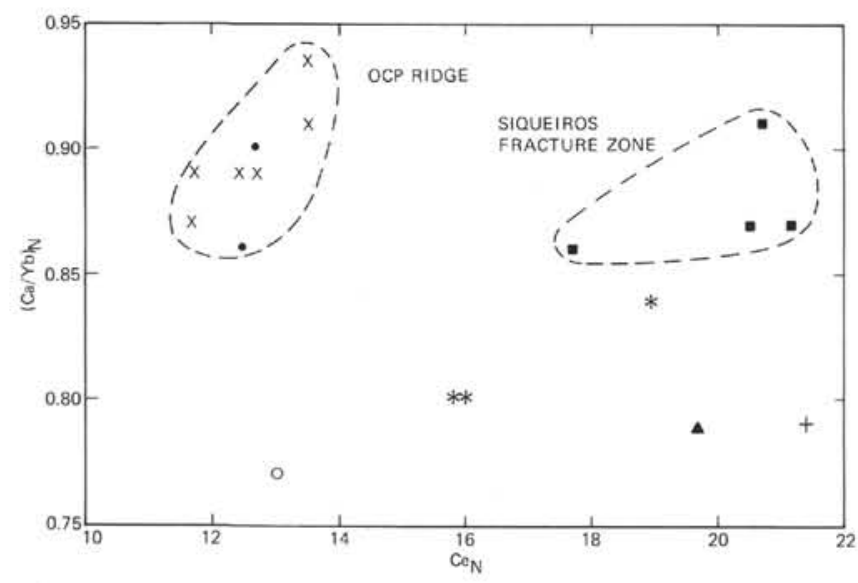

Figure 5. $(\mathrm{Ce} / \mathrm{Yb})_{N}$ ratios versus $\mathrm{Ce}_{N}$ showing the separation of basalts according to structural feature.

The logical conclusion of this line of reasoning is to postulate that the OCP Ridge magmas originated and evolved beneath the EPR, migrating laterally within the upper oceanic crust to the OCP Ridge site immediately before their extrusion. The distance between the OCP Ridge, at the time of its formation, and the EPR cannot be specified precisely until the exact age of the OCP Ridge is known. At present the eastward termination of the OCP Ridge is on crust generated at the EPR slightly more than 1 m.y. ago, about $65 \mathrm{~km}$ from its axis. Sigurdsson and Sparks (1978) have postulated lateral movements of basic magma for distances of up to $70 \mathrm{~km}$ within the Icelandic crust during historic eruptions. It is clearly a possibility that laterally migrating magma may have fed the OCP Ridge.

\section{ACKNOWLEDGMENTS}

We wish to thank the British Museum (Natural History) for providing the $\mathrm{CHN}$ analyser for $\mathrm{H}_{2} \mathrm{O}^{+}$determinations. Thanks are also due to Peter Watkins and Dennis Bailey in the laboratory, and to Paul Suddaby and Neil Wilkinson for assis-

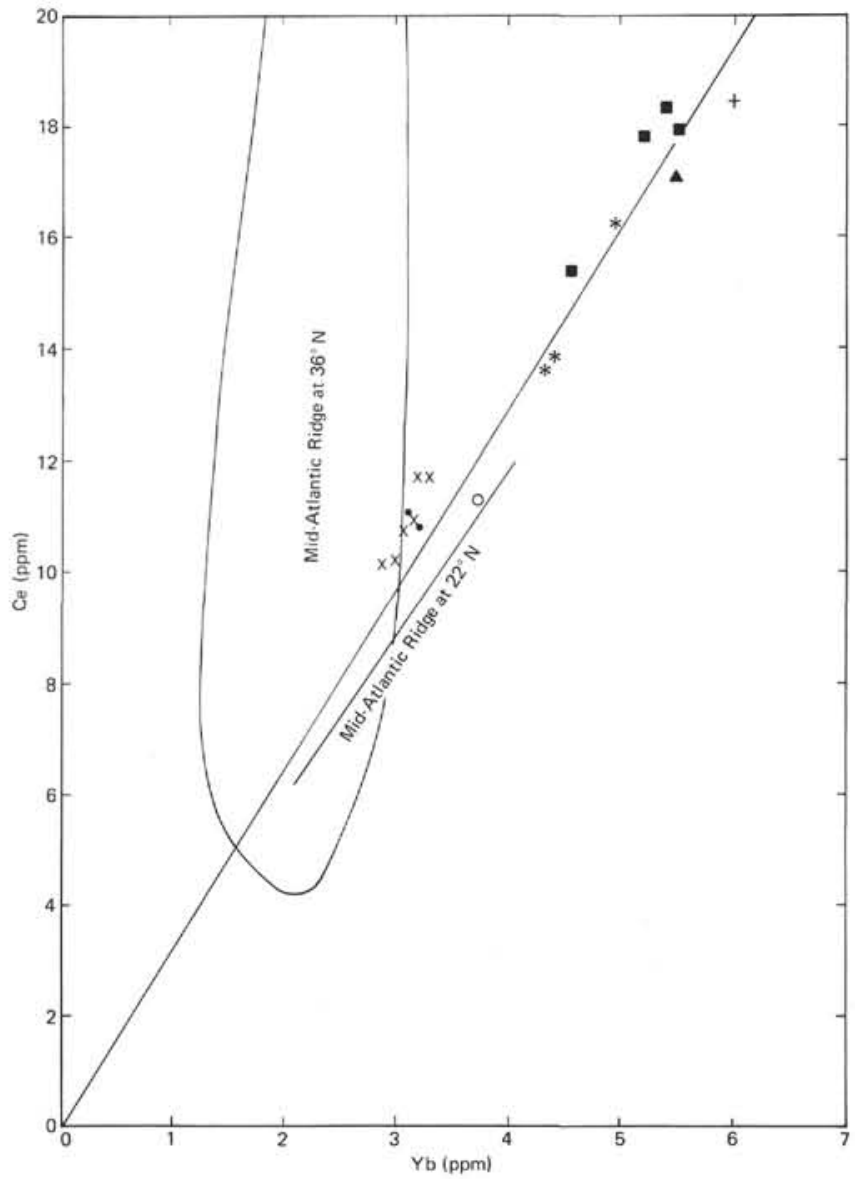

Figure 6. Binary plot of Ce versus $\mathrm{Yb}$ (ppm). (Symbols as for Figure 3.) (Additional data from literature cited in text.)

tance in the operation of the microprobe facility at Imperial College. Finally, Bill Bryan kindly allowed us to use his fractionation modeling program.

This research was supported by NERC Grant GR3/2946. 


\section{REFERENCES}

Batiza, R., Rosendahl, B. R., and Fisher, R. L., 1977. Evolution of oceanic crust. 3. Petrology and chemistry of basalts from the East Pacific Rise and the Siqueiros transform fault. J. Geophys. Res., v. 82, p. 265.

Bonatti, E., 1968. Fissure basalts and ocean floor spreading on the East Pacific Rise. Science, v. 161, p. 886.

Bougault, H., Cambon, P., Corre, O., Joron, J. L., and Treuil, M., 1979. Evidence for variability of magmatic processes and upper mantle heterogeneity in the axial region of the Mid-Atlantic Ridge near $22^{\circ}$ and $36^{\circ} \mathrm{N}$. Tectonophysics, v. 55 , p. 11.

Bougault, H., Treuil, M., and Joron, J. L., 1978. Trace elements from $22^{\circ} \mathrm{N}$ and $36^{\circ} \mathrm{N}$ in the Atlantic Ocean; fractional crystallization, partial melting and heterogeneity of the upper mantle. Leg 45, DSDP. In Melson, W. G., Rabinowitz, P. D. et al., Initial Reports of the Deep Sea Drilling Project, v. 45: Washington (U.S. Govt. Printing Office).

Bryan, W. B., Thompson, G., and Michael, P. J., 1979. Compositional variation in a steady-state zoned magma chamber: Mid-Atlantic Ridge at $36^{\circ} 50^{\prime}$ N. Ibid., v. 55, p. 63 .

Cann, J. R., 1971. Major element variations in ocean floor basalts. Phil. Trans. Roy. Soc. London, A, v. 268, p. 495.

Clague, D. A., and Bunch, T. E., 1976. Formation of ferrobasalts at East Pacific mid-ocean spreading centers. J. Geophys. Res., v. 81 , p. 5305.

Delaney, J. R., Muenow, D. W., and Graham, D. G., 1978. Abundance and distribution of water, carbon and sulfur in the glassy rims of submarine pillow basalts. Geochim. Cosmochim. Acta, v. 42, p. 581 .

Engel, A. E. J., Engel, C. G., and Havens, R. G., 1965. Chemical characteristics of oceanic basalts and the upper mantle. Bull. Geol. Soc. Am., v. 76, p. 719.

Flanagan, F. J., 1973. 1972 values for international geochemical reference samples. Geochim. Cosmochim. Acta, v. 37, p. 1189.

Flower, M. F. J., Ohnmacht, W., Schminke, H.-U., Gibson, I. L., Robinson, P. T., and Parker, R., 1978. Petrology and geochemistry of basalts from Hole 396B, Leg 46 . In Dmitriev, L., Heirtzler, J., et al., Initial Reports of the Deep Sea Drilling Project, v. 46: Washington (U.S. Government Printing Office), p. 179.

Kay, R., Hubbard, N. J., and Gast, P. W., 1970. Chemical characteristics and origin of oceanic ridge volcanic rocks. $J$. Geophys. Res., v. 73, p. 5925.

Langmuir, C. H., Bender, J. F., Bence, A. E., Hanson, G. N., and Taylor, S. E., 1977. Petrogenesis of basalts from the FAMOUS area, Mid-Atlantic Ridge. Earth Planet Sci. Lett., v. 22, p. 29.

Melson, W. G., Thompson, G., and van Andel, Tj. H., 1968. Volcanism and metamorphism in the Mid-Atlantic Ridge, $22^{\circ} \mathrm{N}$ latitude. J. Geophys. Res., v. 73, p. 5925.

Morrison, M. A., Thompson, R. N., Gibson, I. L., and Marriner, G. F., in press. Lateral chemical heterogeneity in the Palaeozoic upper mantle beneath the Scottish Hebrides. Phil. Trans. Roy. Soc.

Norrish, J., and Hutton, J. T., 1969. An accurate X-ray spectrographic method for the analysis of a wide range of geologic samples. Geochim. Cosmochim. Acta, v. 33, p. 431.

O'Hara, M. J., 1977. Geochemical evolution during fractional crystallization of a periodically refilled magma chamber. Nature, v. 266, p. 503.
Orcutt, J. A., Kennett, B. L. B., Dorman, L. M., and Prothero, W. A., 1976. Evidence for a low-velocity zone underlying a fast-spreading rise crest. Ibid., v. 256, p. 475.

Rosendahl, B. R., 1976. Evolution of oceanic crust. 2. Constraints, implications, and inferences. J. Geophys. Res., v. 81, p. 5305.

Rosendahl, B. R., Raitt, R. W., Dorman, L. M., Bibee, L. D., Hussong, D. M., and Sutton, G. H., 1976. Evolution of oceanic crust. 1. A geophysical model of the East Pacific Rise crest derived from seismic refraction data. Ibid., v. 81 , p. 5294 .

Sigurdsson, H., and Sparks, S. R. J., 1978. Lateral magma flow within rifted Icelandic crust. Nature, v. 274, p. 126.

Thompson, G., Bryan, W. B., Frey, F. A., Dickey, J. S., and Suen, C. J., 1976. Petrology and geochemistry of basalts from DSDP Leg 34, Nazca Plate. In Yeats, R. S., Hart S. R., et al., Initial Reports of the Deep Sea Drilling Project, v. 34: Washington (U.S. Government Printing Office), p. 215-226.

Whipple, E. R., 1974. A study of Wilson's determination of ferrous iron in silicates. Chem. Geol., v. 14, p. 223.

Wood, D. A., Gibson, I. L., and Thompson, R. N., 1976. Elemental mobility during zeolite facies metamorphism of the Tertiary basalts of eastern Iceland. Contrib. Mineral. Petrol., v. 55, p. 241.

Wood, D. A., Tarney, J., Varet, J., Saunders, A. D., Bougault, H., Joron, J. L., Treuil, M., and Cann, J. R., 1979. Geochemistry of basalts drilled in the North Atlantic by IPOD Leg 49: implications for mantle heterogeneity. Earth Planet. Sci. Lett., v. 42, p. 77.

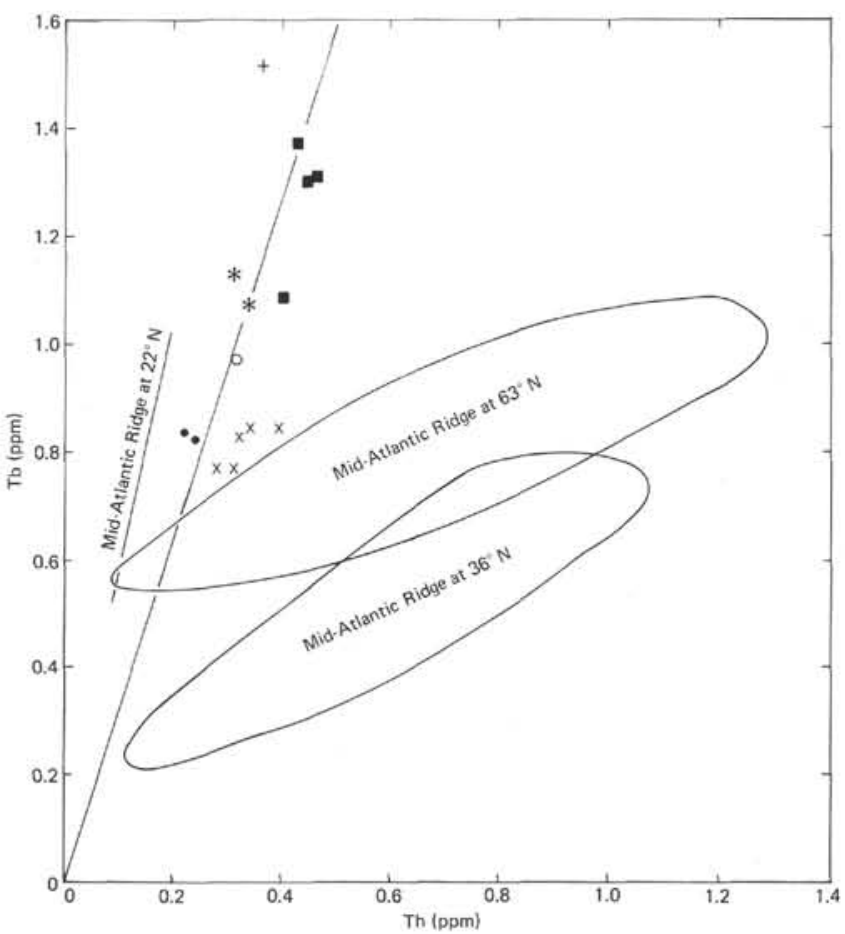

Figure 7. Tb (ppm) plotted against Th (ppm). (Additional data from literatuare cited in text.) 


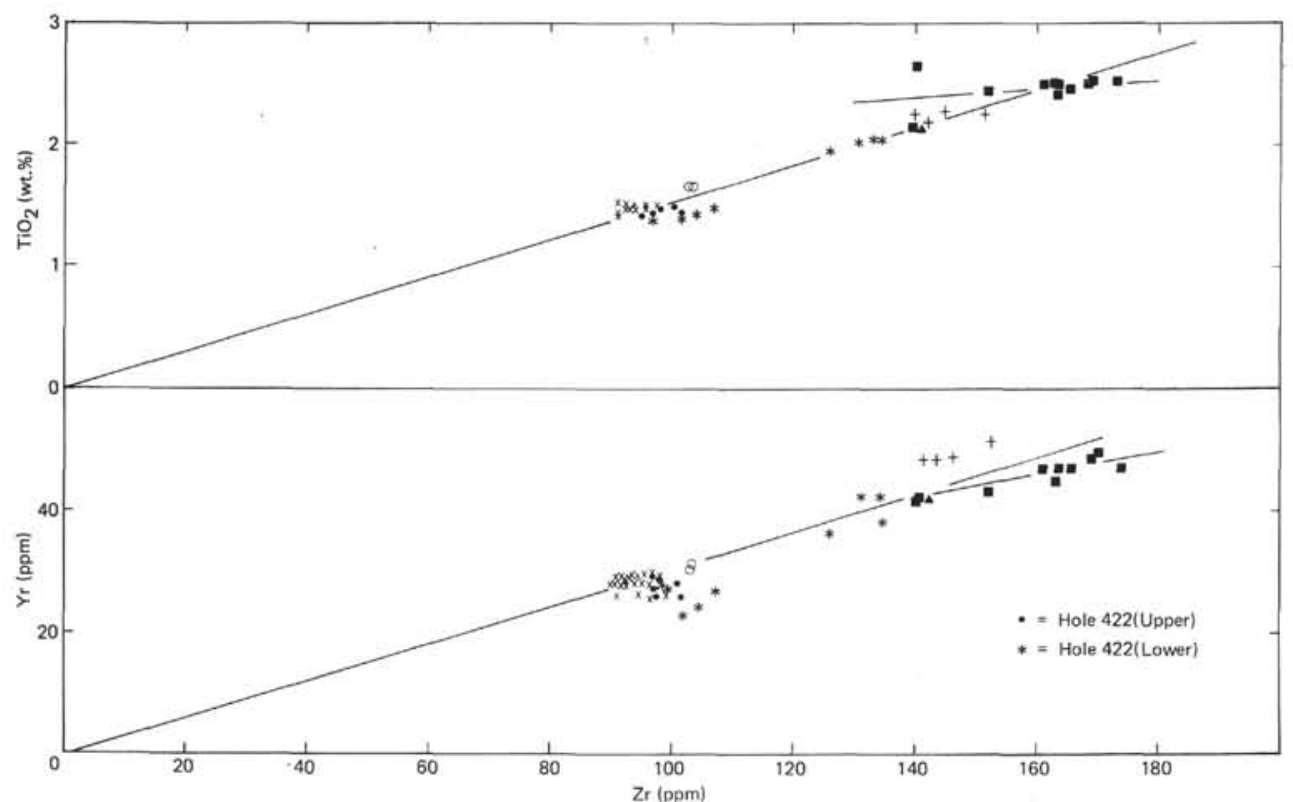

Figure 8. $\mathrm{Y}-\mathrm{Zr}$ and $\mathrm{TiO}_{2}-\mathrm{Zr}$ relationships. (The broken lines indicate general trends, and are not least-square fit lines.)

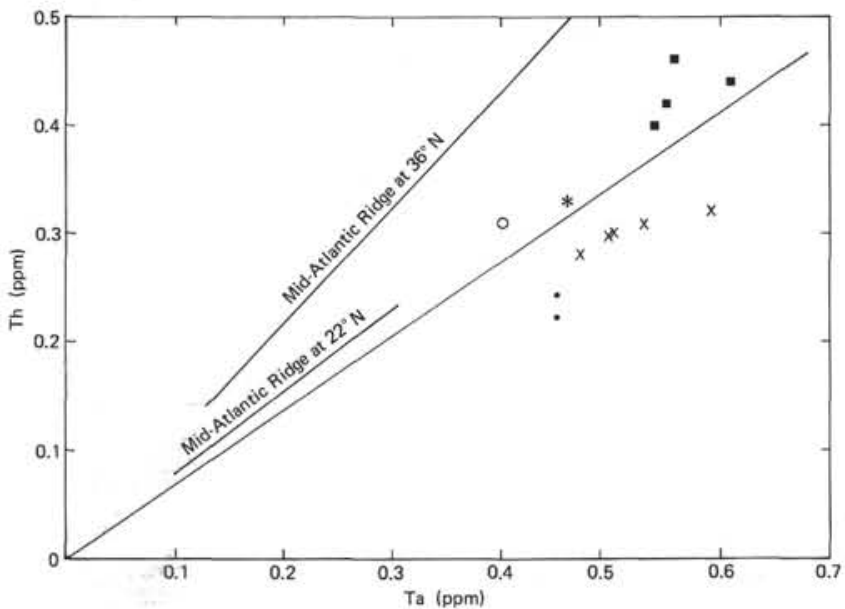

Figure 9. Th (ppm) versus Ta (ppm). (Symbols as for

Figure 3.)

TABLE 8

Intraflow Chemical Variations of Hole 427 Basalts (wt. \%)

Original bulk-rock composition: Section 427-11-1 (Piece 3)

\begin{tabular}{lcc} 
& Analyzed & Calculated $^{\mathrm{a}}$ \\
\hline $\mathrm{SiO}_{2}$ & 50.64 & 50.63 \\
$\mathrm{Al}_{2} \mathrm{O}_{3}$ & 14.23 & 14.23 \\
$\mathrm{FeO}$ & 12.71 & 12.74 \\
$\mathrm{MgO}$ & 6.72 & 6.64 \\
$\mathrm{CaO}$ & 10.95 & 11.04 \\
$\mathrm{Na} 2 \mathrm{O}$ & 3.15 & 3.01 \\
$\mathrm{~K}_{2} \mathrm{O}$ & 0.11 & 0.15 \\
$\mathrm{TiO}_{2}$ & 2.12 & 2.27 \\
$\mathrm{MnO}$ & 0.21 & 0.23 \\
$\mathrm{P}_{2} \mathrm{O}_{5}$ & 0.22 & 0.20 \\
\hline
\end{tabular}

${ }^{a}$ Calculated composition, using Section 427-10-3 (Piece 3) as the derived basalt, with 5.7 per cent plagioclase crystallization and 4.1 per cent pyroxene crystallization. Plagioclase composition: analysis $17 / 1$, Table 3 , Thompson and Humphris (this volume). Pyroxene composition: analysis $17 / 2$, Table 3, Thompson and Humphris (this volume).
TABLE 9

Incompatible Element Enrichments within the Leg 54 Basalt Suite (wt. \%)

\begin{tabular}{lccc}
\hline & $\begin{array}{c}\text { Initial } \\
\text { Concentration }\end{array}$ & $\begin{array}{c}\text { Final } \\
\text { Concentration }\end{array}$ & $C / C_{O}$ \\
\hline $\mathrm{Ce}$ & 10.14 & 18.41 & 1.82 \\
$\mathrm{Nd}$ & 8.58 & 17.55 & 1.83 \\
$\mathrm{~Tb}$ & 0.77 & 1.44 & 1.87 \\
$\mathrm{Yb}$ & 2.92 & 5.67 & 1.94 \\
$\mathrm{Y}$ & 27 & 50 & 1.85 \\
$\mathrm{Zr}$ & 94 & 158 & 1.68 \\
$\mathrm{Hf}$ & 2.23 & 4.26 & 1.91 \\
$\mathrm{Nb}$ & 4 & 5 & 1.25 \\
$\mathrm{Ta}$ & 0.50 & 0.64 & 1.28 \\
$\mathrm{Th}$ & 0.29 & 0.39 & 1.34 \\
$\mathrm{TiO}_{2}$ & 1.47 & 2.39 & 1.63 \\
$\mathrm{P}_{2} \mathrm{O}_{5}$ & 0.15 & 0.26 & 1.73 \\
\hline
\end{tabular}

${ }^{\mathrm{a}}$ Mean of Sections 428A-2-1 (Piece 8) and 428A-4. 2 (Piece 1A).

Mean of Sections 421-4-1 (Piece 5B) and 427-9-4

(Piece 4A)

Elements in ppm; oxides in wt. \%. 